\title{
Nitrogen Release in Soils Amended with Different Organic and Inorganic Fertilizers under Contrasting Moisture Regimes: A Laboratory Incubation Study
}

\author{
Shihab Uddin ${ }^{1}\left(\mathbb{D}\right.$, Mohammad Rafiqul Islam ${ }^{1, *} \mathbb{*}$, Mohammad Mofizur Rahman Jahangir ${ }^{1}(\mathbb{D}$, \\ Mohammad Mojibur Rahman ${ }^{2}$, Sabry Hassan ${ }^{3}{ }^{-}$, Mohamed M. Hassan ${ }^{3}{ }^{(0}$, Ali A. Abo-Shosha ${ }^{4}$, Atef F. Ahmed ${ }^{3}$ \\ and Mohammad Mahmudur Rahman ${ }^{5}$ (i)
}

check for updates

Citation: Uddin, S.; Islam, M.R.; Jahangir, M.M.R.; Rahman, M.M.; Hassan, S.; Hassan, M.M.; Abo-Shosha, A.A.; Ahmed, A.F.; Rahman, M.M. Nitrogen Release in Soils Amended with Different Organic and Inorganic Fertilizers under Contrasting Moisture Regimes: A Laboratory Incubation Study. Agronomy 2021, 11, 2163. https:// doi.org/10.3390/agronomy11112163

Academic Editor: Monika

Mierzwa-Hersztek

Received: 22 September 2021

Accepted: 24 October 2021

Published: 27 October 2021

Publisher's Note: MDPI stays neutral with regard to jurisdictional claims in published maps and institutional affiliations.

Copyright: (c) 2021 by the authors. Licensee MDPI, Basel, Switzerland. This article is an open access article distributed under the terms and conditions of the Creative Commons Attribution (CC BY) license (https:/ / creativecommons.org/licenses/by/ $4.0 /)$.
1 Department of Soil Science, Bangladesh Agricultural University, Myensingh 2202, Bangladesh; shihab43151@bau.edu.bd (S.U.); mmrjahangir@bau.edu.bd (M.M.R.J.)

2 Bangladesh Agricultural Research Institute, Joydebpur, Gazipur 1701, Bangladesh; mojiburbari@gmail.com

3 Department of Biology, College of Science, Taif University, P.O. Box 11099, Taif 21944, Saudi Arabia; hassan@tu.edu.sa (S.H.); m.khyate@tu.edu.sa (M.M.H.); atef.a@gmail.com (A.F.A.)

4 Genetics Department, Faculty of Agriculture, Kafrelsheikh University, Kafr El-Sheikh 33516, Egypt; khyate999@gmail.com

5 Global Centre for Environmental Remediation, College of Engineering, Science and Environment, The University of Newcastle, Callaghan, NSW 2308, Australia; mahmud.rahman@newcastle.edu.au

* Correspondence: rafiqss69@bau.edu.bd

\begin{abstract}
Understanding nitrogen $(\mathrm{N})$ release patterns and kinetics is a key challenge for improving $\mathrm{N}$ use efficiency in any agroecosystem. An incubation experiment was done to study the $\mathrm{N}$ release pattern and kinetics of contrasting soils amended with compost (CO), poultry manure (PM), rice husk biochar (RHB), poultry manure biochar (PMB) and cowdung (CD) combined with chemical fertilizer (integrated plant nutrient system, IPNS approach) under two moisture regimes, viz. field capacity (FC) and continuous standing water (CSW) at $25{ }^{\circ} \mathrm{C}$ for 120 days. Our results revealed that $\mathrm{NH}_{4}{ }^{+}-\mathrm{N}$ was the dominant under CSW conditions, whereas $\mathrm{NO}_{3}{ }^{-}-\mathrm{N}$ was dominant under $\mathrm{FC}$ conditions. Net mineral $\mathrm{N}$ data fitted well to the first order kinetic model. Both $\mathrm{N}$ release potential $\left(\mathrm{N}_{0}\right)$ and rate constant $(\mathrm{k})$ were greater in acidic soil than those of charland soil. The maximum $\mathrm{N}$ release varied between $24.90-76.29 \%$ of input depending on soil type and moisture status. $\mathrm{N}$ mineralization was strongly correlated with urea $\mathrm{N}$ application. PM and PMB mineralized in all soil and moisture conditions whereas $\mathrm{N}$ immobilization was observed in the case of RHB. N mineralization was strongly correlated with urea $\mathrm{N}$ application. Gaseous $\mathrm{N}$ losses were different for the organic amendments exhibiting more gaseous N losses in PM, CD and CO based IPNS whereas the lowest gaseous N loss was observed in PMB based IPNS. Biochar based IPNS increased soil $\mathrm{pH}$ in all conditions. Thus, the present study suggests that $\mathrm{N}$ release depends on soil type, soil moisture and type of organic amendment. However, CO, PM and CD based IPNS can be recommended for both acidic and charland soils in terms of $\mathrm{N}$ release as short duration crops will suffer from $\mathrm{N}$ deficiency if biochar based IPNS is used in the field.
\end{abstract}

Keywords: biochar; nitrogen release; $\mathrm{N}$ release kinetics; integrated plant nutrient system; organic amendment; field capacity; continuous standing water; soil $\mathrm{pH}$

\section{Introduction}

In Bangladesh, SOM content is dwindling day by day as a result of inadequate management, intensive manipulation, and excessive use of chemical fertilizer. Acidic and charland soils in Bangladesh are two deteriorated soils with poor organic matter and nutritional status, posing a hazard to crop productivity on approximately $36 \%$ of the country's land [1,2]. In order to improve crop yields, minimize contamination, and attain sustainable farming, fertility in these soils must be maintained or restored to a sufficient level $[3,4]$. An 
integrated plant nutrient system (IPNS) is an approach that allows for the applying of nutrients from both organic and inorganic sources to reduce the application of synthetic fertilizers, achieve a close fit between nutrient supplies and plant nutrient demands, maintain soil health, and provide a continuous nutrient supply to plants. Organic amendment $(\mathrm{OA})$ is an important nutrient supplier to the plants and a means of soil rejuvenation $[5,6]$. According to some researchers, organic amendments are most effective when combined with mineral fertilizers $[7,8]$. OA, especially cowdung $(\mathrm{CD})$, poultry manure $(\mathrm{PM})$ and biochar (BC), improves soil physical properties [9,10], chemical properties [11,12], and biological properties [13].

Nitrogen $(\mathrm{N})$ is one of the most important yet scarce elements in all ecological systems, and it influences ecosystem functioning significantly $[14,15]$. The conversion of $\mathrm{N}$ from organic to inorganic form is known as mineralization, and the reversal of the process is known as immobilization [16]. The net mineralization or net immobilization of the resultant consequences of these two processes determines the nitrogen supply to growing crops. Many factors influence mineralization processes, including organic matter source, soil properties [17,18], crop management [19], and other soil environmental factors, particularly temperature, moisture, and soil $\mathrm{pH}[20,21]$. Lehmann and Joseph [22] described biochar as a carbon-rich substance produced from the pyrolysis of organic material at low temperatures. Biochar can modulate soil $\mathrm{N}$ dynamics by boosting nitrification [23], lowering denitrification [24], adsorbing $\mathrm{NH}_{4}{ }^{+}$and reducing ammonia volatilization [25,26], minimizing $\mathrm{N}_{2} \mathrm{O}$ emission [24,27] and enhancing crop's $\mathrm{N}$ bioavailability [25]. However, biochar application has not always enhanced $\mathrm{N}$ release $[28,29]$, but was also found to have little or no effect [28-30], or to even reduce $\mathrm{N}$ release [31,32]. These incoherent results may be due to the differences in biochar feedstock, the pyrolytic condition, soil properties, or various other underlying processes as reported previously. The soil moisture regime is one of the key factors affecting the $\mathrm{N}$ mineralization process [33]. Soil moisture affects $\mathrm{N}$ release through regulating oxygen consumption rates, as well as microorganism specific growth rates and enzymatic activity [34]. Field capacity conditions of soil moisture favor N mineralization, resulting in greater mineral $\mathrm{N}$ release compared to the saturated or continuous standing water conditions [35,36]. Guntiñas et al. [37] reported that soil moisture at $80 \%$ of the field capacity was optimum for $\mathrm{N}$ mineralization. In contrast, Ono [38] postulated that flooding increased soil $\mathrm{pH}$ as well as $\mathrm{N}$ mineralization. Therefore, the effect of soil moisture on $\mathrm{N}$ mineralization is still a controversy and needs further research to reach a conclusion.

Previous research on $\mathrm{N}$ mineralization dynamics was mostly focused on $\mathrm{N}$ release from only OAs in agricultural ecosystems, such as livestock manures, plant residues, and composts $[35,36,39]$. As OAs differ considerably in composition and degree of stability, and their ability to release nutrients is frequently overlooked or exaggerated, resulting in nutrient shortages or plant toxicity [40]. Nutrients in organic chemical structures are generally complex; this implies that organic amendments can serve as a slow-release fertilizer, and the amount of nutrients released is highly dependent on the rate and degree of mineralization. The mineralization process is aided by the use of chemical fertilizer as it lowers the C:N ratio of the soil [41]. IPNS is necessary for improving nutrient availability as sole application of OAs may cause nutrient shortage and sole application of chemical fertilizer enhances plant toxicity and environmental hazards [40]. It is still unclear how much of the applied N (i.e., IPNS basis) will be available to the current crop, when to apply IPNS for synchronization of $\mathrm{N}$ release and plant requirements, and how environmental factors influence $\mathrm{N}$ release in acidic and charland soils. Thus, the present laboratory incubation study was designed to (1) evaluate the $\mathrm{N}$ release pattern and kinetics of different IPNS treatments in two degraded $\mathrm{N}$ poor soils of Bangladesh under different moisture regimes; (2) measure the changes in soil total nitrogen (STN) and soil mineral $\mathrm{N}$ after the addition of various IPNS treatments during the incubation period; and (3) investigate the subsequent changes in soil $\mathrm{pH}$ as a result of IPNS treatments throughout the incubation period. 


\section{Materials and Methods}

\subsection{Soil Sampling and Preparation}

24 soil samples (8-10 kg each) for both acidic soil and charland soil were collected at 0-15 cm depth from an agricultural field of 0.072 ha. Acidic soil samples were collected from Madhupur, Mymensingh ( $\left.24^{\circ} 59.82^{\prime} \mathrm{N}, 90^{\circ} 03.99^{\prime} \mathrm{E}\right)$ and charland soil samples from Islampur, Jamalpur $\left(25^{\circ} 80.73^{\prime} \mathrm{N}, 89^{\circ} 81.90^{\prime} \mathrm{E}\right)$. Madhupur belongs to the Madhupur Tract (AEZ-28) and Islampur to the Old Brahmaputra Floodplain (AEZ-9). The general soil type of the acid soil is a deep red to brown terrace soil [42] and the charland soil is a Non-Calcareous Dark Grey Floodplain Soil [42]. In the laboratory, 24 soil samples were mixed to make a composite soil sample in each type and spread on brown paper to air dry. To remove roots and other debris, the air-dry soil was crushed and passed through a 2-mm sieve. After sieving, the soil was kept in a polyethylene bag and water was added to wet the soil to $50-72 \%$ of water holding capacity, and then incubated aerobically for three weeks at $25^{\circ} \mathrm{C}$ in order to reduce the effect of handling on soil microbial respiration before the start of the incubation experiment. Table 1 shows the physicochemical properties of the soils under experiment.

Table 1. Physical and chemical properties of the soils.

\begin{tabular}{ccc}
\hline Characteristics & Acidic Soil & Charland Soil \\
\hline \multicolumn{2}{c}{ Mechanical fractions (USDA system) } & \\
Sand $(0.2-0.02) \mathrm{mm} \%$ & 34.24 & 58.91 \\
Silt $(0.02-0.002 \mathrm{~mm}) \%$ & 35.95 & 31.95 \\
Clay $(<0.002 \mathrm{~mm}) \%$ & 29.81 & 9.14 \\
Textural class & Clay loam & Sandy loam \\
Bulk density $\left(\mathrm{g} \mathrm{cm}^{-3}\right)$ & 1.18 & 1.29 \\
Organic matter $(\%)$ & 1.84 & 0.88 \\
Water holding capacity (\%) & 24.10 & 17.28 \\
pH & 5.45 & 6.56 \\
Total N $\left(\mathrm{g} \mathrm{kg}^{-1} \mathrm{soil}^{-1}\right)$ & 0.90 & 0.50 \\
Available P $\left(\mathrm{mg} \mathrm{kg}^{-1}\right)$ & 7.37 & 6.95 \\
Exchangeable K $\left(\mathrm{mg} \mathrm{kg}^{-1}\right)$ & 70.20 & 62.40 \\
Available S $\left(\mathrm{mg} \mathrm{kg}^{-1}\right)$ & 13.26 & 19.50 \\
\hline
\end{tabular}

\subsection{Collection of Organic Materials}

Five types of organic materials, viz. compost (CO), poultry manure (PM), rice husk biochar (RHB), poultry manure biochar (PMB) and cowdung (CD) were used in this study. Compost was collected from Mazim Agro Industries ltd., poultry manure from a poultry farm of Bangladesh Agricultural University (BAU), rice husk (mainly unfilled grains) from the warehouse of the BAU farm, and cowdung was collected from the dairy farm of BAU, Mymensingh. Rice husk biochar and poultry manure biochar were prepared at the Soil Science Field Laboratory, BAU. Biochars were produced by an anaerobic pyrolysis process at $400{ }^{\circ} \mathrm{C}$ for $2-2.5 \mathrm{~h}$. The manures were air dried to $15 \%$ moisture content, pulverized and sieved with a 2-mm mesh. Table 2 shows the chemical compositions of the manures.

Table 2. Chemical properties of different organic amendments.

\begin{tabular}{cccccccccccc}
\hline Manure & $\mathbf{C ~ ( \% )}$ & $\mathbf{N}(\mathbf{\%})$ & $\mathbf{P ~ ( \% )}$ & $\mathbf{K ~ ( \% )}$ & $\mathbf{S ~ ( \% )}$ & $\mathbf{C : N}$ & $\mathbf{C : P}$ & $\mathbf{C : K}$ & $\mathbf{C : S}$ & $\mathbf{p H}$ & $\mathbf{C E C}(\mathbf{m e q} / \mathbf{1 0 0} \mathbf{g})$ \\
\hline CO & 15.27 & 0.61 & 0.08 & 0.11 & 0.04 & 25.0 & 190.9 & 138.8 & 381.8 & 7.3 & 10.07 \\
PM & 28.56 & 1.85 & 0.08 & 0.10 & 0.08 & 15.4 & 357.0 & 285.6 & 357.0 & 8.3 & 12.29 \\
RHB & 38.62 & 1.57 & 0.11 & 0.13 & 0.11 & 24.6 & 351.1 & 297.1 & 351.1 & 7.5 & 19.54 \\
PMB & 47.76 & 2.74 & 0.14 & 0.14 & 0.13 & 17.4 & 341.1 & 341.1 & 367.4 & 8.5 & 35.68 \\
CD & 25.02 & 1.40 & 0.09 & 0.10 & 0.09 & 17.9 & 278.0 & 250.2 & 278.0 & 7.6 & 14.11 \\
\hline
\end{tabular}




\subsection{Incubation Experiment}

The experiment was laid out in a factorial design with three replications. The experiment comprised three main factors, i.e., soil type (acidic soil and charland soil), moisture level (field capacity and $1 \mathrm{~cm}$ of standing water) and treatments. Treatments included compost + chemical fertilizers, poultry manure + chemical fertilizers, rice husk biochar + chemical fertilizers, poultry manure biochar + chemical fertilizers, and cowdung + chemical fertilizers. Organic amendments were applied at $6 \mathrm{tha}^{-1}\left(4 \mathrm{~g} \mathrm{~kg}^{-1}\right.$ soil). All of the treatments were applied at a rate of $120 \mathrm{mg} \mathrm{N} \mathrm{kg}^{-1}$ soil on an $\mathrm{N}$-equivalent basis. $\mathrm{N}$ was applied from both organic and chemical fertilizer (i.e., urea) in all the treatments. Table 3 is the summary table of the $\mathrm{N}$ sources from various treatments. $\mathrm{P}, \mathrm{K}$, and $\mathrm{S}$ were also added in the form of triple superphosphate (TSP), muriate of potash (MoP) and gypsum fertilizer (dry), respectively, at rates of $10.67,50.67$, and $4 \mathrm{mg} \mathrm{P,} \mathrm{K}$, and $\mathrm{S} \mathrm{kg}^{-1}$ soil, respectively, to each plastic container. Altogether, there were twenty treatments [2 $\times 2 \times 5$ (two moisture levels for each soil)] with three replications of each. Unamended soil was incubated as control, to calculate net $\mathrm{N}$ mineralization by subtracting amount of mineral $\mathrm{N}$ in amended soils with amount if mineral $\mathrm{N}$ in control. A total of $250 \mathrm{~g}$ soil was weighed into a succession of plastic containers on an oven dry weight basis. During the entire incubation period, 648 plastic containers were used (i.e., 540 for the treatments and 108 for control (unamended soil)). The organic additions were fully incorporated into the soil (except control). To stabilize microbial activity, the soil moisture content was adjusted 1 week before to actual incubation to maintain field capacity (22-25\% moisture) and $1 \mathrm{~cm}$ standing water conditions. The soils in the plastic containers were incubated at room temperature $\left(25^{\circ} \mathrm{C}\right)$ for up to 120 days. A polythene covering was placed over each container to avoid evaporation and quick loss of water. Every other day, the containers were weighed, and the weight loss was supplemented with distilled water. Incubation period involved nine sampling dates, i.e., $0,3,7,15,21,30,60,90$, and 120 days (after amendments application). For $\mathrm{N}$ quantification, destructive sampling was used to take a series of samples at each sampling date. The results were adjusted for moisture content and expressed on a dry weight basis determined in the oven.

Table 3. Summary of the nitrogen source from different treatments used in the experiment.

\begin{tabular}{|c|c|c|}
\hline Treatment Combination & $\begin{array}{l}\mathrm{N} \text { from Organic Amendment } \\
\left(\mathrm{mg} \mathrm{N} \mathrm{kg}^{-1} \text { Soil) }\right.\end{array}$ & $\begin{array}{l}\mathrm{N} \text { from Chemical Fertilizer } \\
\text { i.e., Urea ( } \mathrm{mg} \mathrm{N} \mathrm{kg}^{-1} \text { Soil) }\end{array}$ \\
\hline Control & 0 & 0 \\
\hline $\mathrm{CO}+\mathrm{CF}$ & 51.2 & 68.8 \\
\hline $\mathrm{PM}+\mathrm{CF}$ & 74.0 & 46.0 \\
\hline $\mathrm{RHB}+\mathrm{CF}$ & 62.8 & 57.2 \\
\hline $\mathrm{PMB}+\mathrm{CF}$ & 98.8 & 21.2 \\
\hline $\mathrm{CD}+\mathrm{CF}$ & 56.0 & 64.0 \\
\hline
\end{tabular}

i.e., $\mathrm{CO}=$ compost; $\mathrm{CF}=$ chemical fertilizer; $\mathrm{PM}=$ poultry manure; $\mathrm{RHB}=$ rice husk biochar; $\mathrm{PMB}=$ poultry manure biochar; and $\mathrm{CD}=$ cowdung.

\subsection{Soil Extraction and Analysis}

Total nitrogen (TN), mineral nitrogen $\left(\mathrm{NH}_{4}{ }^{+}-\mathrm{N}\right.$ and $\left.\mathrm{NO}_{3}{ }^{-}-\mathrm{N}\right)$, and soil $\mathrm{pH}$ were measured in soil samples from all treatments incubated at various intervals. Extraction of soil samples immediately after incorporation of each amendment was used to determine the initial concentration of $\mathrm{TN}$ and mineral $\mathrm{N}$ at day zero.

\subsubsection{Mineral N}

Mineral $\mathrm{N}$ was determined by colorimetric method [43]. For this purpose, $50 \mathrm{~g}$ soil sample from each plastic container was extracted by shaking with $125 \mathrm{~mL} 2 \mathrm{M} \mathrm{KCl}$ (soil: $\mathrm{KCl}$ solution $=1: 2.5$ ) for $2 \mathrm{~h}$, after that filtration was done using Whatman No. 41 filter paper. To determine $\mathrm{NH}_{4}{ }^{+}-\mathrm{N}, 25 \mathrm{~mL}$ of the aliquot was steam distilled with $0.7 \mathrm{~g}$ of $\mathrm{MgO}$ for $4 \mathrm{~min}$ and the ammonia was trapped in a $20 \mathrm{~mL}$ boric acid indicator solution similar to 
total $\mathrm{N}$ determination. Then $0.3 \mathrm{~g}$ more $\mathrm{MgO}$ and $0.4 \mathrm{~g}$ Devarda's alloy were added to the same aliquot derived after first distillation for $\mathrm{NO}_{3}{ }^{-}-\mathrm{N}$ determination. Before starting the second distillation, the conical flask containing $20 \mathrm{~mL}$ boric acid indicator solution was replaced with a fresh boric acid indicator. After completion of distillation, the colour of the boric acid indicator solution changed from pink to green and the indicator solutions were then titrated with $0.1 \mathrm{~N} \mathrm{H}_{2} \mathrm{SO}_{4}$ separately to determine the concentration of $\mathrm{NH}_{4}{ }^{+}-\mathrm{N}$ and $\mathrm{NO}_{3}{ }^{-}-\mathrm{N}[43]$.

\subsubsection{Total $\mathrm{N}$}

Total $\mathrm{N}$ was determined using Kjeldahl method [44]. The soil derived after extraction of mineral $\mathrm{N}$ was then oven dried. $1 \mathrm{~g}$ of oven-dried ground soil sample, $1.1 \mathrm{~g}$ catalyst mixture $\left(\mathrm{K}_{2} \mathrm{SO}_{4}: \mathrm{CuSO}_{4} \cdot 5 \mathrm{H}_{2} \mathrm{O}: \mathrm{Se}=100: 10: 1\right)$, and $5 \mathrm{~mL} \mathrm{H}_{2} \mathrm{SO}_{4}$ were added to a digestion flask. After swirling the flasks, they were set aside for around $10 \mathrm{~min}$. The digest was then heated to $380^{\circ} \mathrm{C}$ until it was clear and colourless. After cooling, the contents were transferred to a $100 \mathrm{~mL}$ volumetric flask and filled with distilled water to the desired volume. In the same way, a reagent blank was made. The total $\mathrm{N}$ content of this digest was determined. For distillation, $40 \% \mathrm{NaOH}$ was added to the digest after it was finished digesting. The ammonia was trapped in a $4 \% \mathrm{H}_{3} \mathrm{BO}_{3}$ solution with five drops of bromocresol green $\left(\mathrm{C}_{21} \mathrm{H}_{14} \mathrm{Br}_{4} \mathrm{~S}\right)$ and methyl red $\left(\mathrm{C}_{10} \mathrm{H}_{10} \mathrm{~N}_{3} \mathrm{O}_{3}\right)$ mixed indicator solution. Finally, standard $0.01 \mathrm{~N} \mathrm{H}_{2} \mathrm{SO}_{4}$ was used to titrate the distillate until the colour changed from green to pink [44]. The amount of $\mathrm{N}$ was calculated using the following formula:

$$
\mathrm{TN}\left(\mathrm{g} \mathrm{kg}^{-1}\right)=\frac{(\mathrm{T}-\mathrm{B}) \times \mathrm{N} \times 0.0144 \times 100 \times 10000}{\mathrm{~S} \times 1000}
$$

where, $\mathrm{T}=$ Sample titration value $(\mathrm{mL})$ of standard $\mathrm{H}_{2} \mathrm{SO}_{4} ; \mathrm{B}=$ Blank titration value $(\mathrm{mL})$ of standard $\mathrm{H}_{2} \mathrm{SO}_{4} ; \mathrm{N}=$ concentration of $\mathrm{H}_{2} \mathrm{SO}_{4} ; \mathrm{S}=$ Sample weight in gram; 4 = Dilution factor.

\subsubsection{Soil $\mathrm{pH}$}

$20 \mathrm{~g}$ oven dry soil sample was taken to measure soil $\mathrm{pH}$ with the help of a glass electrode $\mathrm{pH}$ meter using a soil:water suspension of 1:2.5, as described by Peech [45].

\subsection{Calculating Net Mineral N Data, Maximum N Release, N Release Per Unit Urea and Gaseous} N Loss

The net mineralization data was calculated by subtracting the mineral $\mathrm{N}$ of unamended soil from mineral $\mathrm{N}$ data of amended soil at a particular sampling date [46].

Net mineral $\mathrm{N}=$ Mineral N content in amended soil - Mineral N content in unamended soil

Maximum $\mathrm{N}$ release is the highest amount of net mineral $\mathrm{N}$ content of a particular treatment during the entire sampling period [46].

$\mathrm{N}$ release per unit urea was calculated by following equation:

$$
\mathrm{N} \text { release per unit urea }=\frac{\text { Mean mineral } \mathrm{N} \text { conc. in a treatment }(\mathrm{mg} / \mathrm{kg})}{\text { Urea } \mathrm{N} \text { applied in a particular treatment }(\mathrm{mg})}
$$

If, the value of $\mathrm{N}$ release per unit urea $>1$, it indicates mineralization of organic amendment and if the value of $\mathrm{N}$ release per unit urea $<1$, it indicates immobilization of urea $\mathrm{N}$ fertilizer

Gaseous N loss was calculated by following equation [41]:

Gaseous N loss = Loss of total N - Mineral N conc. after 120 days of incubation

(note: all the units are expresses in $\mathrm{mg} \mathrm{N} \mathrm{kg}^{-1}$ )

where, loss of total $\mathrm{N}$ is the difference between initial and final total $\mathrm{N}$ concentration. 


\subsection{Fitting of $N$ Release Data to the First Order Kinetic Model}

Different kinetic models were used to fit the net $\mathrm{N}$ release values. The first-order kinetic model provided the best fit. An exponential equation was used to compute the $\mathrm{N}$ release potential $\left(\mathrm{N}_{0}\right)$ and rate constant $(\mathrm{k})$ for various sources of organic materials [47].

The equation for $\mathrm{N}$ kinetics was

$$
\mathrm{N}_{\mathrm{t}}=\mathrm{N}_{0}\left(1-\mathrm{e}^{-\mathrm{kt}}\right)
$$

where, $\mathrm{N}_{\mathrm{t}}$ is the net $\mathrm{N}$ release at time $\mathrm{t}, \mathrm{N}_{0}$ is the $\mathrm{N}$ release potential, and $\mathrm{k}$ is the rate constant.

\subsection{Statistical Analysis}

The data were subjected to three-way analysis of variance (ANOVA) technique using Statistix 10 software package by Factorial Design. Normality of residuals and homogeneity of variances were checked before performing ANOVA. $\mathrm{N}$ release kinetics were determined using Sigma-Plot 14.0 software. Post-hoc tests were performed to separate differences among treatments using the Tukey-Kramer multiple comparison. All statistical analyses were considered significant at $p \leq 0.05$, unless otherwise mentioned. Correlations between total mineral N (TMN) and STN were calculated using Microsoft EXCEL package (Microsoft Corporation, Pullman, WA, USA).

\section{Results}

\section{1. $\mathrm{NH}_{4}{ }^{+}-\mathrm{N}$ Release}

The release of $\mathrm{NH}_{4}{ }^{+}-\mathrm{N}$ from the IPNS treatments was significantly influenced by the soil types $(p<0.01)$, soil moisture regimes $(p<0.001)$, and treatment combination $(p<0.01)$. The $\mathrm{NH}_{4}{ }^{+}-\mathrm{N}$ was significantly higher in acidic soil than in charland soil $(p<0.01)$, exhibiting a mean value of 24.20 and $19.65 \mathrm{mg} \mathrm{N} \mathrm{kg}^{-1}$, respectively, in acidic soil and charland soil, irrespective of soil moisture status and treatment combination (Table 4). With regard to soil moisture status, the mean $\mathrm{NH}_{4}{ }^{+}-\mathrm{N}$ was significantly higher in soils kept under continuous standing water (CSW) compared to the soils kept under field capacity (FC), being 35.47 and $8.38 \mathrm{mg} \mathrm{N} \mathrm{kg}^{-1}$ soil, respectively, in CSW and FC, irrespective of all other factors (Table 4). Likewise, the highest mean $\mathrm{NH}_{4}{ }^{+}-\mathrm{N}$ release was observed in compost + chemical fertilizer $(\mathrm{CO}+\mathrm{CF})$, which was identical to cowdung + chemical fertilizer $(\mathrm{CD}+\mathrm{CF})$ and poultry manure + chemical fertilizer $(\mathrm{PM}+\mathrm{CF})$, whereas the lowest value was observed in poultry manure biochar + chemical fertilizer $(\mathrm{PMB}+\mathrm{CF})($ Table 4). The interactions between soil type and moisture status had a significant effect on $\mathrm{NH}_{4}{ }^{+}-\mathrm{N}$ release, recording the highest value in acidic soil with CSW, and the lowest value in either soil type with FC. Treatment combinations and soil moisture status interactions had also significant effect on $\mathrm{NH}_{4}{ }^{+}-\mathrm{N} . \mathrm{CO}+\mathrm{CF}, \mathrm{CD}+\mathrm{CF}$ and $\mathrm{PM}+\mathrm{CF}$ with $\mathrm{CSW}$ had the highest $\mathrm{NH}_{4}{ }^{+}-\mathrm{N}$ release than any other combination. In contrast, soil type and treatment combination interactions were non-significant. Similarly, three-way interactions were non-significant.

Table 4. Mean $\mathrm{NH}_{4}{ }^{+}-\mathrm{N}, \mathrm{NO}_{3}{ }^{-}-\mathrm{N}$, Mineral $\mathrm{N}$ concentration and $\mathrm{pH}$ of different soil type, moisture status and treatments (mean $\pm \mathrm{SE}) ; n=3$.

\begin{tabular}{|c|c|c|c|c|}
\hline & $\begin{array}{c}\mathrm{Net}_{\mathrm{NH}_{4}}^{+} \\
\text {Concentration } \\
\left(\mathrm{mg} \mathrm{N} \mathrm{kg}{ }^{-1}\right)\end{array}$ & $\begin{array}{c}\text { Net } \mathrm{NO}_{3}^{-} \\
\text {Concentration } \\
\left(\mathrm{mg} \mathrm{N} \mathrm{kg}{ }^{-1}\right)\end{array}$ & $\begin{array}{c}\text { Net Mineral N } \\
\text { Concentration } \\
\left(\mathrm{mg} \mathrm{N} \mathrm{kg}^{-1}\right)\end{array}$ & Soil pH \\
\hline \multicolumn{5}{|l|}{ Soil type } \\
\hline $\begin{array}{c}\text { Acidic soil } \\
\text { Charland soil } \\
\text { level of significance }\end{array}$ & $\begin{array}{c}24.2 \pm 5.38 \mathrm{a} \\
19.7 \pm 4.22 \mathrm{~b} \\
* *\end{array}$ & $\begin{array}{c}26.6 \pm 8.37 \mathrm{a} \\
23.7 \pm 7.61 \mathrm{~b} \\
* * *\end{array}$ & $\begin{array}{c}50.8 \pm 4.46 \mathrm{a} \\
36.9 \pm 2.83 \mathrm{~b} \\
* * *\end{array}$ & $\begin{array}{c}5.6 \pm 0.11 \mathrm{~b} \\
6.5 \pm 0.06 \mathrm{a} \\
* * *\end{array}$ \\
\hline
\end{tabular}


Table 4. Cont.

\begin{tabular}{|c|c|c|c|c|}
\hline & $\begin{array}{c}\text { Net } \mathrm{NH}_{4}^{+} \\
\text {Concentration } \\
\left(\mathrm{mg} \mathrm{N} \mathrm{kg}{ }^{-1}\right)\end{array}$ & 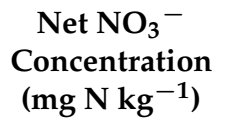 & $\begin{array}{c}\text { Net Mineral N } \\
\text { Concentration } \\
\left(\mathrm{mg} \mathrm{N} \mathrm{kg}^{-1}\right)\end{array}$ & Soil pH \\
\hline \multicolumn{5}{|l|}{ Moisture Status } \\
\hline FC & $8.4 \pm 0.67 b$ & $48.1 \pm 3.30 \mathrm{a}$ & $50.8 \pm 4.46 \mathrm{a}$ & $5.8 \pm 0.17 b$ \\
\hline $\begin{array}{c}\text { CSW } \\
\text { level of significance }\end{array}$ & $35.5 \pm \underset{* * *}{2.58} \mathrm{a}$ & $2.2 \pm \underset{* * *}{0.17 \mathrm{~b}}$ & $36.9 \pm \underset{* * *}{ \pm} 2.83 \mathrm{~b}$ & $\underset{* * *}{6.3 \pm 0.13 \mathrm{a}}$ \\
\hline \multicolumn{5}{|l|}{ Treatments } \\
\hline $\mathrm{CO}+\mathrm{CF}$ & $26.6 \pm 9.47 \mathrm{a}$ & $31.6 \pm 16.69 \mathrm{a}$ & $53.6 \pm 7.85 \mathrm{a}$ & $5.9 \pm 0.29 b$ \\
\hline $\mathrm{PM}+\mathrm{CF}$ & $23.1 \pm 9.08 \mathrm{ab}$ & $25.3 \pm 13.27 b$ & $45.9 \pm 4.52 \mathrm{ab}$ & $6.0 \pm 0.32 \mathrm{ab}$ \\
\hline $\mathrm{RHB}+\mathrm{CF}$ & $18.9 \pm 6.97 \mathrm{~b}$ & $21.4 \pm 11.44 \mathrm{c}$ & $38.2 \pm 5.17 \mathrm{~b}$ & $6.2 \pm 0.25 \mathrm{a}$ \\
\hline $\mathrm{PMB}+\mathrm{CF}$ & $16.0 \pm 5.46 \mathrm{c}$ & $18.1 \pm 9.59 \mathrm{~d}$ & $31.2 \pm 4.37 c$ & $6.2 \pm 0.26 \mathrm{a}$ \\
\hline $\mathrm{CD}+\mathrm{CF}$ & $25.0 \pm 9.12 \mathrm{a}$ & $29.4 \pm 15.62 \mathrm{a}$ & $50.3 \pm 7.11 \mathrm{a}$ & $6.0 \pm 0.31 \mathrm{ab}$ \\
\hline level of significance & $* *$ & $* * *$ & $* *$ & $*$ \\
\hline \multicolumn{5}{|l|}{ Statistical analysis for interaction } \\
\hline Soil type $\times$ Soil Moisture & $* *$ & ** & $* * *$ & $* * *$ \\
\hline Soil type $\times$ Treatment & ns & $* * *$ & ** & * \\
\hline Soil Moisture $\times$ Treatment & ** & $* *$ & $* *$ & * \\
\hline Soil type $\times$ Soil Moisture $\times$ Treatment & ns & ns & ns & ns \\
\hline
\end{tabular}

i.e., $\mathrm{CO}=$ compost, $\mathrm{CF}=$ chemical fertilizer, $\mathrm{PM}=$ poultry manure, $\mathrm{RHB}=$ rice husk biochar, $\mathrm{PMB}=$ poultry manure biochar, $\mathrm{CD}=\mathrm{cowdung}$, $\mathrm{FC}=$ field capacity, CSW $=$ continuous standing water. ns indicates non-significant, ${ }^{*}$ indicates significant at $5 \%$ level of significance, ${ }^{* *}$ indicates significant at $1 \%$ level of significance, ${ }^{* * *}$ indicates significant at $0.1 \%$ level of significance.

\section{2. $\mathrm{NO}_{3}{ }^{-}-\mathrm{N}$ Releases}

$\mathrm{NO}_{3}{ }^{-}-\mathrm{N}$ release was significantly influenced by soil type $(p<0.001)$, soil moisture status $(p<0.001)$ and treatment combination $(p<0.001)$. Irrespective of moisture status and treatment, significantly higher $\mathrm{NO}_{3}{ }^{-}-\mathrm{N}$ was observed in acidic soil than in charland soil (ca. 26.58 and $23.70 \mathrm{mg} \mathrm{N} \mathrm{kg}^{-1}$ soil in acidic soil and charland soil, respectively) (Table 4). The $\mathrm{NO}_{3}{ }^{-}-\mathrm{N}$ was significantly higher in $\mathrm{FC}$ than in CSW, displaying a mean value of 48.13 and $2.16 \mathrm{mg} \mathrm{N} \mathrm{kg}^{-1}$ soil, respectively, in FC and CSW, irrespective of soil type and treatment combinations (Table 4). Likewise, $\mathrm{CO}+\mathrm{CF}$ had the highest $\mathrm{NO}_{3}{ }^{-}-\mathrm{N}$, which was similar to $\mathrm{CD}+\mathrm{CF}$, whereas $\mathrm{PMB}+\mathrm{CF}$ showed the lowest value (Table 4). Treatment combinations and soil moisture status interactions had a significant effect on $\mathrm{NO}_{3}{ }^{-} \mathrm{N}$ production. $\mathrm{CO}+\mathrm{CF}$ produced the highest $\mathrm{NO}_{3}{ }^{-}-\mathrm{N}$ while $\mathrm{PMB}+\mathrm{CF}$ produced the lowest amount of $\mathrm{NO}_{3}{ }^{-}-\mathrm{N}$ under FC conditions. Similar trend was also observed in case of CSW condition. Similarly, soil type and treatment combination interactions were also significant. $\mathrm{OF}+\mathrm{CF}$ had the highest and $\mathrm{PMB}+\mathrm{CF}$ had the lowest $\mathrm{NO}_{3}{ }^{-}-\mathrm{N}$ concentration in both soils. In contrast, three-way interactions were non-significant.

\subsection{Mineral $\mathrm{N}\left(\mathrm{NH}_{4}{ }^{+}-\mathrm{N}+\mathrm{NO}_{3}{ }^{-}-\mathrm{N}\right)$ Releases}

The availability of $\mathrm{N}\left(\mathrm{NH}_{4}{ }^{+}-\mathrm{N}+\mathrm{NO}_{3}{ }^{-}-\mathrm{N}\right)$ was significantly influenced by soil types $(p<0.001$, Table 4$)$. The mean mineral $\mathrm{N}$ was higher in acidic soil than in charland soil, being 50.78 and $36.93 \mathrm{mg} \mathrm{N} \mathrm{kg}^{-1}$ soil, respectively, irrespective of all other factors. Likewise, soil moisture status also influenced the mean mineral $\mathrm{N}(p<0.001$, Table 4$)$. $\mathrm{N}$ mineralization was higher in soils kept under FC moisture status than in soils with CSW of $1 \mathrm{~cm}$ (ca. 50.78 and $36.93 \mathrm{mg} \mathrm{N} \mathrm{kg}^{-1}$ soil in FC and CSW, respectively). Mineral $\mathrm{N}$ content was significantly influenced by treatment combinations $(p<0.001$, Table 4$)$. The highest mean mineral $\mathrm{N}$ was observed in $\mathrm{CO}+\mathrm{CF}$, which was similar to $\mathrm{CD}+\mathrm{CF}$, and the lowest mineral $\mathrm{N}$ was found in $\mathrm{PMB}+\mathrm{CF}$. The trend of mineral $\mathrm{N}$ showed that the mineral $\mathrm{N}$ content reached its peak at day 7, and remained more or less constant in the case of acidic soil incubated at FC, and decreased thereafter with time in charland soil with FC and CSW conditions in both the soil types (Figure 1). 

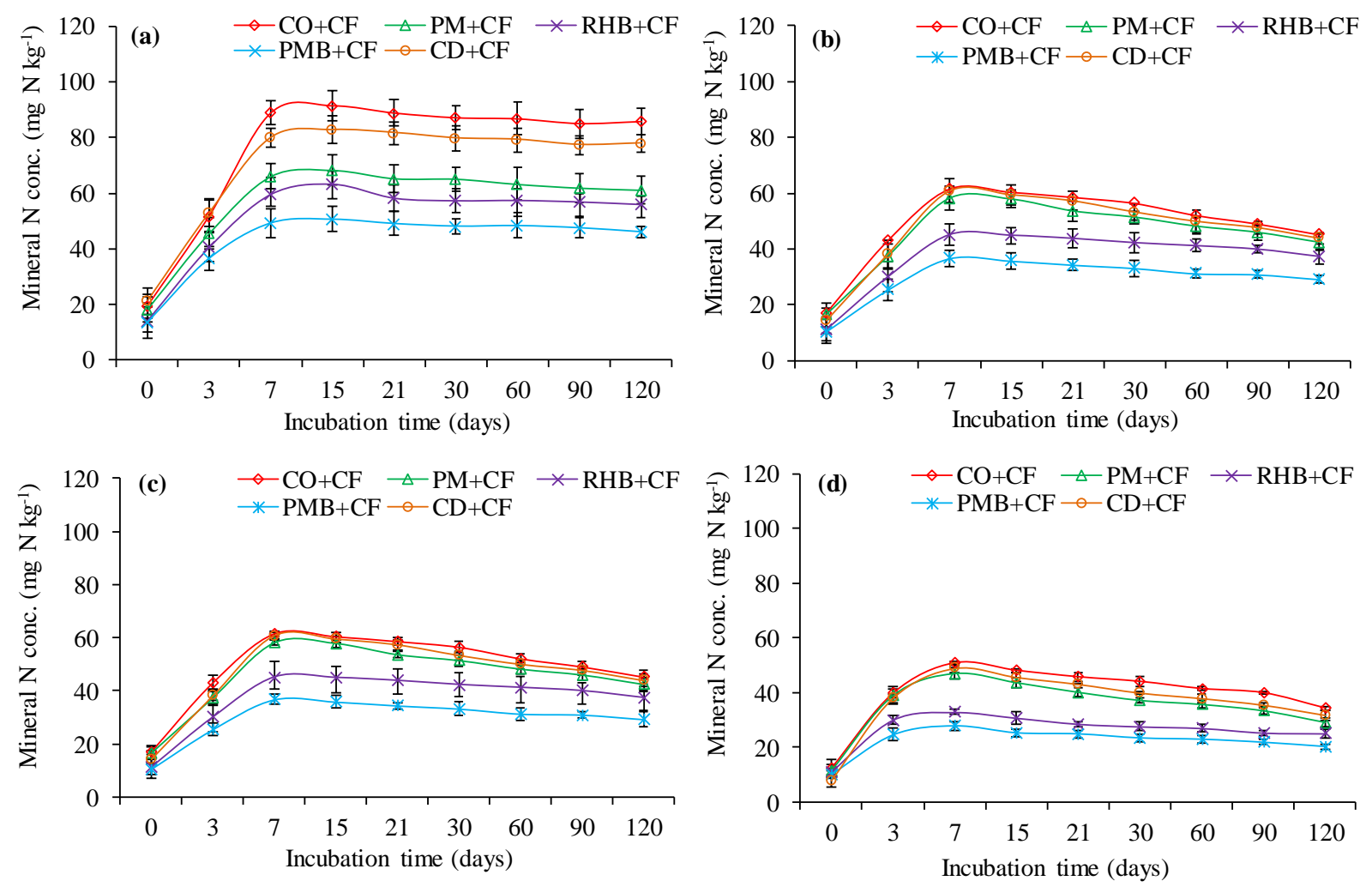

Figure 1. Trend of net mineral $\mathrm{N}\left(\mathrm{NH}_{4}{ }^{+}-\mathrm{N}+\mathrm{NO}_{3}{ }^{-}-\mathrm{N}\right)$ mineralization from different treatments in (a) acidic soil with $\mathrm{FC}$; (b) acidic soil with CSW; (c) charland soil with FC; and (d) charland soil with CSW. Net mineralization is calculated as the difference in amount between amended soil and control. Error bars represent standard errors of the means $(n=3)$.

The interaction effects of the soil type and soil moisture status were significant. The highest mineral $\mathrm{N}$ was observed in either soil type having FC moisture status, and the lowest value was observed in either soil type with CSW. Considering the soil type and treatment combination interactions, mean mineral $\mathrm{N}$ was significantly higher in acidic soil treated with $\mathrm{CO}+\mathrm{CF}$, which was statistically similar to $\mathrm{CD}+\mathrm{CF}$ and $\mathrm{PM}+\mathrm{CF}$ in either soil, whereas the lowest value was observed in either soil with PMB + CF. Likewise, treatment combination and soil moisture status interactions had a significant effect on mean mineral $\mathrm{N}$, exhibiting the highest mineral $\mathrm{N}$ content in $\mathrm{CO}+\mathrm{CF}$ with $\mathrm{FC}$ which was identical to $\mathrm{CD}+\mathrm{CF}$ along with FC moisture status and lowest value in PMB + CF with FC and CSW, respectively. Unlike interactions among soil types, treatment combinations and soil moisture status were found to be non-significant.

\subsection{Nitrogen Release Kinetics}

The net $\mathrm{N}$ mineralization data for all the treatments in both soil type and moisture status were fitted well to the first order kinetic model $\left(\mathrm{N}_{\mathrm{t}}=\mathrm{N}_{0}\left(1-\mathrm{e}^{-\mathrm{kt}}\right)\right)$. The adjusted $\mathrm{R}^{2}$ values ranged from 0.565 to 0.870 when mineral $\mathrm{N}$ data were fitted to the first order kinetic model (Table 5). The $\mathrm{N}$ mineralization potential and rate constant for different treatment combinations were calculated for both the soil type and moisture status (Table 4). In both soils, mineralization potential for treatments was higher under FC compared to CSW. In both the soils and moisture status, among the treatments, $\mathrm{CO}+\mathrm{CF}$ showed the highest mineralization potential, followed by $\mathrm{CD}+\mathrm{CF}, \mathrm{PM}+\mathrm{CF}, \mathrm{RHB}+\mathrm{CF}$, and $\mathrm{PMB}+$ $\mathrm{CF}$ (Table 1$)$. The $\mathrm{N}$ release potential $\left(\mathrm{N}_{0}\right)$ of the treatment combination was significantly influenced by soil type $(p<0.001)$, soil moisture status $(p<0.001)$, and treatment combination $(p<0.001)$. The $\mathrm{N}_{0}$ was significantly higher in acidic soil than in charland soil, being 57.42 and $48.50 \mathrm{mg} \mathrm{N} \mathrm{kg}^{-1}$ soil in acidic soil and charland soil, respectively, irrespective of moisture status and treatment combination. FC moisture status had higher $\mathrm{N}_{0}$ than in CSW moisture status (ca. 64.09 and 41.63 in FC and CSW, respectively) irrespective of soil 
type and treatment combination. The highest $\mathrm{N}_{0}$ was observed in $\mathrm{CO}+\mathrm{CF}$ and $\mathrm{CD}+\mathrm{CF}$ than in any other treatment combination (Table 4).

Table 5. Parameter values, regression equation and coefficients of determination for the $\mathrm{N}$ release kinetics of soils amended with different organic sources along with chemical fertilizers under two moisture status during 120 days of incubation.

\begin{tabular}{|c|c|c|c|c|c|c|c|}
\hline Soil Type & $\begin{array}{l}\text { Moisture } \\
\text { Status }\end{array}$ & $\begin{array}{l}\text { Treatment } \\
\text { Combination }\end{array}$ & $\begin{array}{c}\mathrm{N}_{0} \\
\left(\mathrm{mg} \mathrm{N} \mathrm{kg} \mathrm{Ng}^{-1}\right. \\
\text { Soil) }\end{array}$ & $\begin{array}{c}\mathrm{k} \\
\left(\mathrm{mg} \mathrm{N} \mathrm{kg}^{-1}\right. \\
\text { Soil Day } \\
\text {-1) }\end{array}$ & $\begin{array}{l}\text { Regression } \\
\text { Equation }\end{array}$ & $\mathbf{R}^{2}$ adj * & $p$-Value \\
\hline \multirow[t]{10}{*}{ Acidic soil } & \multirow[t]{5}{*}{ FC } & $\mathrm{CO}+\mathrm{CF}$ & 88.20 & 0.885 & $y=1.175 x-15.32$ & 0.870 & $p<0.0001$ \\
\hline & & $\mathrm{PM}+\mathrm{CF}$ & 64.57 & 0.648 & $y=1.302 x-19.26$ & 0.775 & $p<0.0001$ \\
\hline & & $\mathrm{RHB}+\mathrm{CF}$ & 58.73 & 0.589 & $y=1.247 x-14.30$ & 0.843 & $p<0.0001$ \\
\hline & & $\mathrm{PMB}+\mathrm{CF}$ & 48.63 & 0.488 & $y=1.332 x-15.83$ & 0.801 & $p<0.0001$ \\
\hline & & $\mathrm{CD}+\mathrm{CF}$ & 80.31 & 0.806 & $y=1.282 x-22.13$ & 0.830 & $p<0.0001$ \\
\hline & \multirow[t]{5}{*}{ CSW } & $\mathrm{CO}+\mathrm{CF}$ & 54.68 & 0.54 & $y=1.195 x-11.51$ & 0.594 & $p<0.0001$ \\
\hline & & $P M+C F$ & 50.90 & 0.503 & $y=1.164 x-9.27$ & 0.565 & $p<0.0001$ \\
\hline & & $\mathrm{RHB}+\mathrm{CF}$ & 42.12 & 0.416 & $y=1.240 x-10.22$ & 0.764 & $p<0.0001$ \\
\hline & & $\mathrm{PMB}+\mathrm{CF}$ & 32.99 & 0.326 & $y=1.281 x-9.48$ & 0.641 & $p<0.0001$ \\
\hline & & $\mathrm{CD}+\mathrm{CF}$ & 53.02 & 0.524 & $y=1.104 x-6.45$ & 0.667 & $p<0.0001$ \\
\hline \multirow[t]{10}{*}{ Charland soil } & \multirow[t]{5}{*}{ FC } & $\mathrm{CO}+\mathrm{CF}$ & 75.66 & 0.577 & $y=1.249 x-18.41$ & 0.855 & $p<0.0001$ \\
\hline & & $\mathrm{PM}+\mathrm{CF}$ & 61.10 & 0.466 & $y=1.480 x-28.71$ & 0.597 & $p<0.0001$ \\
\hline & & $\mathrm{RHB}+\mathrm{CF}$ & 50.51 & 0.385 & $y=1.422 x-20.93$ & 0.709 & $p<0.0001$ \\
\hline & & $\mathrm{PMB}+\mathrm{CF}$ & 43.99 & 0.335 & $y=1.384 x-16.60$ & 0.743 & $p<0.0001$ \\
\hline & & $\mathrm{CD}+\mathrm{CF}$ & 69.23 & 0.528 & $y=1.367 x-24.96$ & 0.670 & $p<0.0001$ \\
\hline & \multirow[t]{5}{*}{ CSW } & $\mathrm{CO}+\mathrm{CF}$ & 45.92 & 0.487 & $y=1.253 x-11.87$ & 0.750 & $p<0.0001$ \\
\hline & & $P M+C F$ & 39.20 & 0.416 & $y=1.142 x-6.34$ & 0.608 & $p<0.0001$ \\
\hline & & $\mathrm{RHB}+\mathrm{CF}$ & 29.61 & 0.314 & $y=1.326 x-9.79$ & 0.687 & $p<0.0001$ \\
\hline & & $\mathrm{PMB}+\mathrm{CF}$ & 26.75 & 0.284 & $y=1.203 x-5.57$ & 0.833 & $p<0.0001$ \\
\hline & & $\mathrm{CD}+\mathrm{CF}$ & 43.07 & 0.457 & $y=1.122 x-5.57$ & 0.856 & $p<0.0001$ \\
\hline
\end{tabular}

$\mathrm{R}^{2}$ adj ${ }^{*}$ value: 0.0 to 0.2 - very weak fit, 0.2 to 0.4 - weak fit, 0.4 to 0.7 - moderate fit, 0.7 to 0.9 - strong fit, 0.9 to 1.0 -very strong fit. The regression equations in the table represent the relationship between the calculated value (x) and the predicted value by model (y).

Mineralization rate constant $(\mathrm{k})$ was significantly higher in acidic soil than in charland soil $(p<0.001)$. Likewise, moisture status significantly influenced the mineralization rate $(p<0.001)$. The highest mineralization rate constant was observed in soil kept under CSW rather than in FC. Similarly, mineralization rate constant was significantly influenced by different treatments $(p<0.01)$. $\mathrm{CO}+\mathrm{CF}$ had the highest mineralization rate constant, which was statistically similar to $C D+C F$ and PM $+C F$, whereas biochar based IPNS had the lowest mineralization rate constant (Table 5). The interaction effects between soil type and soil moisture status were significant. Other interactions were non-significant. The calculated net mineral $\mathrm{N}$ concentration and the modeled mineral $\mathrm{N}$ concentration had a linear relationship. The linear regression equations in Table 5 can be used as a tool for calculating the first order kinetic model value of different treatments under different conditions.

The $\mathrm{N}$ release was significantly higher in acidic soil than in charland soil. The $\mathrm{N}$ release ranged from about $30-76 \%$ of $\mathrm{N}$ input in acidic soil, whereas the value was about $25-64 \%$ of $\mathrm{N}$ input in the case of charland soil (Table 6). For both soil types, $\mathrm{N}$ release was significantly higher when incubated at FC than in CSW. A significant amount of $\mathrm{N}$ was released due to the addition of $\mathrm{CO}+\mathrm{CF}$ in both the soil type and moisture status, which was followed by $\mathrm{CD}+\mathrm{CF}, \mathrm{PM}+\mathrm{CF}, \mathrm{RHB}+\mathrm{CF}$, and PMB $+\mathrm{CF}$ (Table 6). N release per unit urea application is the indication of the sources of mineral $\mathrm{N}$. The data of $\mathrm{N}$ release per unit urea application revealed that mineral $\mathrm{N}$ came from both organic and inorganic sources in most of the cases in acidic soil compared to the charland soil. The results revealed that FC conditions were more favourable for mineralization of organic sources, whereas immobilization took place in most of the cases under CSW conditions (Table 6). PM and PMB mineralized in both soil types and moisture regimes. Immobilization of urea $\mathrm{N}$ took 
place in $\mathrm{CO}+\mathrm{CF}, \mathrm{RHB}+\mathrm{CF}$ and $\mathrm{CD}+\mathrm{CF}$ in all the cases except in acidic soil kept under FC conditions.

Table 6. Maximum net mineral $\mathrm{N}$ release, $\% \mathrm{~N}$ release, and $\mathrm{N}$ release per unit urea of different soil type, moisture status and treatments.

\begin{tabular}{|c|c|c|c|c|c|}
\hline Soil Type & Moisture Regime & Treatment & $\begin{array}{l}\text { Maximum Net Mineral N } \\
\left(\mathrm{mg} \mathrm{N} \mathrm{kg}^{-1}\right)\end{array}$ & $\begin{array}{l}\text { N Release } \\
\text { (\% of Input) }\end{array}$ & $\begin{array}{c}\text { N Release } \\
\text { (Per Unit Urea) }\end{array}$ \\
\hline \multirow[t]{10}{*}{ Acidic soil } & FC & $\mathrm{CO}+\mathrm{CF}$ & 91.55 & 76.29 & 1.33 \\
\hline & & $\mathrm{PM}+\mathrm{CF}$ & 68.32 & 56.93 & 1.49 \\
\hline & & $\mathrm{RHB}+\mathrm{CF}$ & 63.38 & 52.82 & 1.11 \\
\hline & & $\mathrm{PMB}+\mathrm{CF}$ & 50.68 & 42.23 & 2.39 \\
\hline & & $\mathrm{CD}+\mathrm{CF}$ & 82.73 & 68.94 & 1.29 \\
\hline & CSW & $\mathrm{CO}+\mathrm{CF}$ & 61.60 & 51.33 & 0.90 \\
\hline & & $\mathrm{PM}+\mathrm{CF}$ & 58.14 & 48.45 & 1.26 \\
\hline & & $\mathrm{RHB}+\mathrm{CF}$ & 45.13 & 37.61 & 0.79 \\
\hline & & $\mathrm{PMB}+\mathrm{CF}$ & 36.66 & 30.55 & 1.73 \\
\hline & & $\mathrm{CD}+\mathrm{CF}$ & 60.76 & 50.64 & 0.95 \\
\hline \multirow[t]{10}{*}{ Charland soil } & FC & $\mathrm{CO}+\mathrm{CF}$ & 61.60 & 51.33 & 0.90 \\
\hline & & $\mathrm{PM}+\mathrm{CF}$ & 58.14 & 48.45 & 1.26 \\
\hline & & $\mathrm{RHB}+\mathrm{CF}$ & 45.13 & 37.61 & 0.79 \\
\hline & & $\mathrm{PMB}+\mathrm{CF}$ & 36.66 & 30.55 & 1.73 \\
\hline & & $\mathrm{CD}+\mathrm{CF}$ & 60.76 & 50.64 & 0.95 \\
\hline & CSW & $\mathrm{CO}+\mathrm{CF}$ & 50.76 & 42.30 & 0.74 \\
\hline & & $\mathrm{PM}+\mathrm{CF}$ & 46.98 & 39.15 & 1.02 \\
\hline & & $\mathrm{RHB}+\mathrm{CF}$ & 32.77 & 27.31 & 0.57 \\
\hline & & $\mathrm{PMB}+\mathrm{CF}$ & 27.87 & 23.23 & 1.31 \\
\hline & & $\mathrm{CD}+\mathrm{CF}$ & 48.83 & 40.69 & 0.76 \\
\hline
\end{tabular}

\subsection{Nitrogen Balance}

The initial total $\mathrm{N}$ concentration was 1020 and $620 \mathrm{mg} \mathrm{N} \mathrm{kg}^{-1}$ in acidic and charland soil, respectively. The final total $\mathrm{N}$ concentration ranged from 928.4 to $983.3 \mathrm{mg} \mathrm{N} \mathrm{kg}^{-1}$ in acidic soil and 558.4 to $592.1 \mathrm{mg} \mathrm{N} \mathrm{kg}^{-1}$ in charland soil, respectively (Table 7). A decreasing trend of changes in soil total $\mathrm{N}$ during the 120 days of incubation was observed (Figure S1). Nitrogen balance of acidic soil and charland soil amended with organic and inorganic fertilizer under FC and CSW conditions after 120 days of incubation period are shown in Table 7. Data revealed that total $\mathrm{N}$ loss ranged from 27.9 to $91.6 \mathrm{mg} \mathrm{kg}^{-1}$ soil. Total N loss was $31.7 \%$ higher in acidic soil than in charland soil. Similarly, total N loss was $31.7 \%$ higher in FC conditions compared to the CSW conditions. The highest total $\mathrm{N}$ loss was observed in $\mathrm{CO}+\mathrm{CF}$ and the lowest in PMB $+\mathrm{CF}$. Unaccounted N loss/Gaseous $\mathrm{N}$ loss (volatilization \& denitrification) was $40.4 \%$ higher in charland soil than in acidic soil. Likewise, gaseous $\mathrm{N}$ loss was significantly higher under CSW conditions compared to the FC conditions. Considering treatment combination, gaseous $\mathrm{N}$ loss was significantly higher in $\mathrm{PM}+\mathrm{CF}, \mathrm{CD}+\mathrm{CF}$ and $\mathrm{CO}+\mathrm{CF}$ whereas the lowest gaseous $\mathrm{N}$ loss was observed in $\mathrm{PMB}+\mathrm{CF}$. 
Table 7. Nitrogen balance $\left(\mathrm{mg} \mathrm{kg}^{-1}\right)$ of different soil type, moisture status and treatments after 120 days of incubation.

\begin{tabular}{|c|c|c|c|c|c|c|c|}
\hline Soil Type & $\begin{array}{l}\text { Moisture } \\
\text { Regime }\end{array}$ & Treatment & $\begin{array}{c}\text { Initial } \\
\text { Total N } \\
\left(\mathrm{mg} \mathrm{N} \mathrm{kg}^{-1}\right)\end{array}$ & $\begin{array}{l}\text { Final Total } N \\
\left(\mathrm{mg} \mathrm{N} \mathrm{kg}^{-1}\right)\end{array}$ & $\begin{array}{c}\text { Loss of } \\
\text { Total N } \\
\left(\mathrm{mg} \mathrm{N} \mathrm{kg}^{-1}\right)\end{array}$ & $\begin{array}{c}\text { Mineral N } \\
\text { Conc. after } \\
120 \text { Days } \\
\left(\mathrm{mg} \mathrm{N} \mathrm{kg}^{-1}\right)\end{array}$ & $\begin{array}{c}\text { Unaccounted } \\
\text { N/Gaseous } \\
\text { N Loss } \\
\left(\mathrm{mg} \mathrm{N} \mathrm{kg}^{-1}\right)\end{array}$ \\
\hline \multirow[t]{10}{*}{ Acidic soil } & \multirow[t]{5}{*}{ FC } & $\mathrm{CO}+\mathrm{CF}$ & 1020.0 & 928.4 & 91.6 & 85.9 & 5.7 \\
\hline & & $\mathrm{PM}+\mathrm{CF}$ & 1020.0 & 951.7 & 68.3 & 61.2 & 7.1 \\
\hline & & $\mathrm{RHB}+\mathrm{CF}$ & 1020.0 & 956.6 & 63.4 & 56.1 & 7.3 \\
\hline & & $\mathrm{PMB}+\mathrm{CF}$ & 1020.0 & 969.3 & 50.7 & 46.1 & 4.6 \\
\hline & & $\mathrm{CD}+\mathrm{CF}$ & 1020.0 & 937.3 & 82.7 & 78.0 & 4.7 \\
\hline & \multirow[t]{5}{*}{ CSW } & $\mathrm{CO}+\mathrm{CF}$ & 1020.0 & 958.4 & 61.6 & 45.2 & 16.4 \\
\hline & & $\mathrm{PM}+\mathrm{CF}$ & 1020.0 & 961.9 & 58.1 & 42.3 & 15.8 \\
\hline & & $\mathrm{RHB}+\mathrm{CF}$ & 1020.0 & 974.9 & 45.1 & 37.4 & 7.7 \\
\hline & & $\mathrm{PMB}+\mathrm{CF}$ & 1020.0 & 983.3 & 36.7 & 29.2 & 7.5 \\
\hline & & $\mathrm{CD}+\mathrm{CF}$ & 1020.0 & 959.2 & 60.8 & 43.8 & 17.0 \\
\hline \multirow[t]{10}{*}{ Charland soil } & \multirow[t]{5}{*}{ FC } & $\mathrm{CO}+\mathrm{CF}$ & 620.0 & 558.4 & 61.6 & 45.2 & 16.4 \\
\hline & & $\mathrm{PM}+\mathrm{CF}$ & 620.0 & 561.9 & 58.1 & 42.3 & 15.8 \\
\hline & & $\mathrm{RHB}+\mathrm{CF}$ & 620.0 & 574.9 & 45.1 & 37.4 & 7.7 \\
\hline & & $\mathrm{PMB}+\mathrm{CF}$ & 620.0 & 583.3 & 36.7 & 29.2 & 7.5 \\
\hline & & $\mathrm{CD}+\mathrm{CF}$ & 620.0 & 559.2 & 60.8 & 43.8 & 17.0 \\
\hline & \multirow[t]{5}{*}{ CSW } & $\mathrm{CO}+\mathrm{CF}$ & 620.0 & 569.2 & 50.8 & 34.3 & 16.5 \\
\hline & & $\mathrm{PM}+\mathrm{CF}$ & 620.0 & 573.0 & 47.0 & 29.1 & 17.9 \\
\hline & & $\mathrm{RHB}+\mathrm{CF}$ & 620.0 & 587.2 & 32.8 & 25.0 & 7.8 \\
\hline & & $\mathrm{PMB}+\mathrm{CF}$ & 620.0 & 592.1 & 27.9 & 20.2 & 7.7 \\
\hline & & $\mathrm{CD}+\mathrm{CF}$ & 620.0 & 571.2 & 48.8 & 31.6 & 17.2 \\
\hline
\end{tabular}

\subsection{Changes in Soil $p H$}

The trend of changes in soil $\mathrm{pH}$ showed that soil moisture status had a significant influence on soil $\mathrm{pH}$ (Figure S2). In both the soils incubated at FC, all the treatments significantly decreased soil $\mathrm{pH}$ after 120 days of incubation compared to the initial soil $\mathrm{pH}$ except $\mathrm{RHB}+\mathrm{CF}$ and $\mathrm{PMB}+\mathrm{CF}$ (Figure 2). In contrast, soil pH significantly increased in both the soils incubated at CSW (Figure 2). Charland soil had a significantly higher $\mathrm{pH}$ than acidic soil (ca. 6.47 and 5.60 in charland soil and acidic soil, respectively) $(p<0.001)$. Likewise, soil moisture and treatment combinations also significantly influenced soil $\mathrm{pH}$ $(p<0.001)$. Soil pH was significantly higher in CSW than in FC (ca. 6.23 and 5.84 in CSW and $\mathrm{FC}$, respectively). Irrespective of soil type and soil moisture status, $\mathrm{RMB}+\mathrm{CF}$ and $\mathrm{PHB}+\mathrm{CF}$ had higher soil $\mathrm{pH}$ than any other treatment combinations, being 6.19, 6.18, 6.02, 5.98, 5.97 and 5.87 in $\mathrm{RHB}+\mathrm{CF}, \mathrm{PMB}+\mathrm{CF}, \mathrm{CD}+\mathrm{CF}, \mathrm{PM}+\mathrm{CF}$, control and $\mathrm{CO}+\mathrm{CF}$, respectively. Interactions between soil type and soil moisture were significant. Charland soil incubated at CSW had higher soil pH than any other combination. Similarly, interactions between soil type and treatment combination were also significant. The charland soil treated with either of the treatments had significantly higher soil $\mathrm{pH}$ than treated acidic soil. Likewise, soil moisture status and treatment combination had a significant influence on soil $\mathrm{pH}$. $\mathrm{RHB}+\mathrm{CF}$ and PMB $+\mathrm{CF}$ treated soils incubated at CSW had a higher soil pH than any other combination, which were similar to $\mathrm{PM}+\mathrm{CF}$ and $\mathrm{CD}+\mathrm{CF}$ treated soils incubated at CSW. The three-way interactions were non-significant.

Nitrogen mineralization was very strongly correlated with urea $\mathrm{N}$ application in both soil types and moisture regimes (Figure 3). The $\mathrm{R}^{2}$ value ranged from 0.61 to 0.75 in different combinations. The highest correlation was observed in acidic soil kept under FC conditions and the lowest in charland soil kept under CSW conditions. 

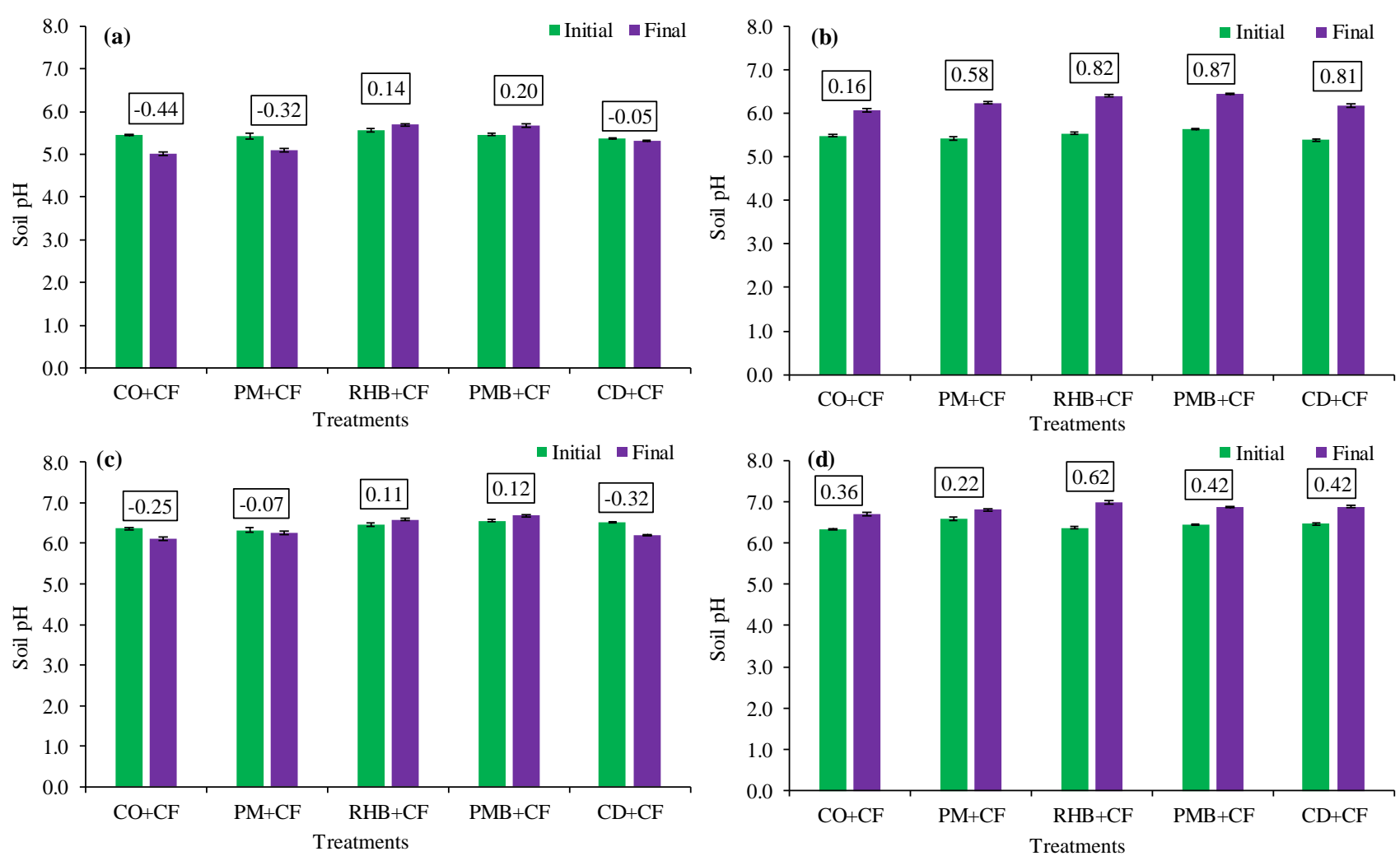

Figure 2. Changes in soil $\mathrm{pH}$ after 120 days of incubation of different treatments in (a) acidic soil with FC; (b) acidic soil with CSW; (c) charland soil with FC; and (d) charland soil with CSW. Values in the box represents delta $\mathrm{pH}, \Delta \mathrm{pH}$. $\Delta \mathrm{pH}=$ Final $\mathrm{pH}$-Initial $\mathrm{pH}$.
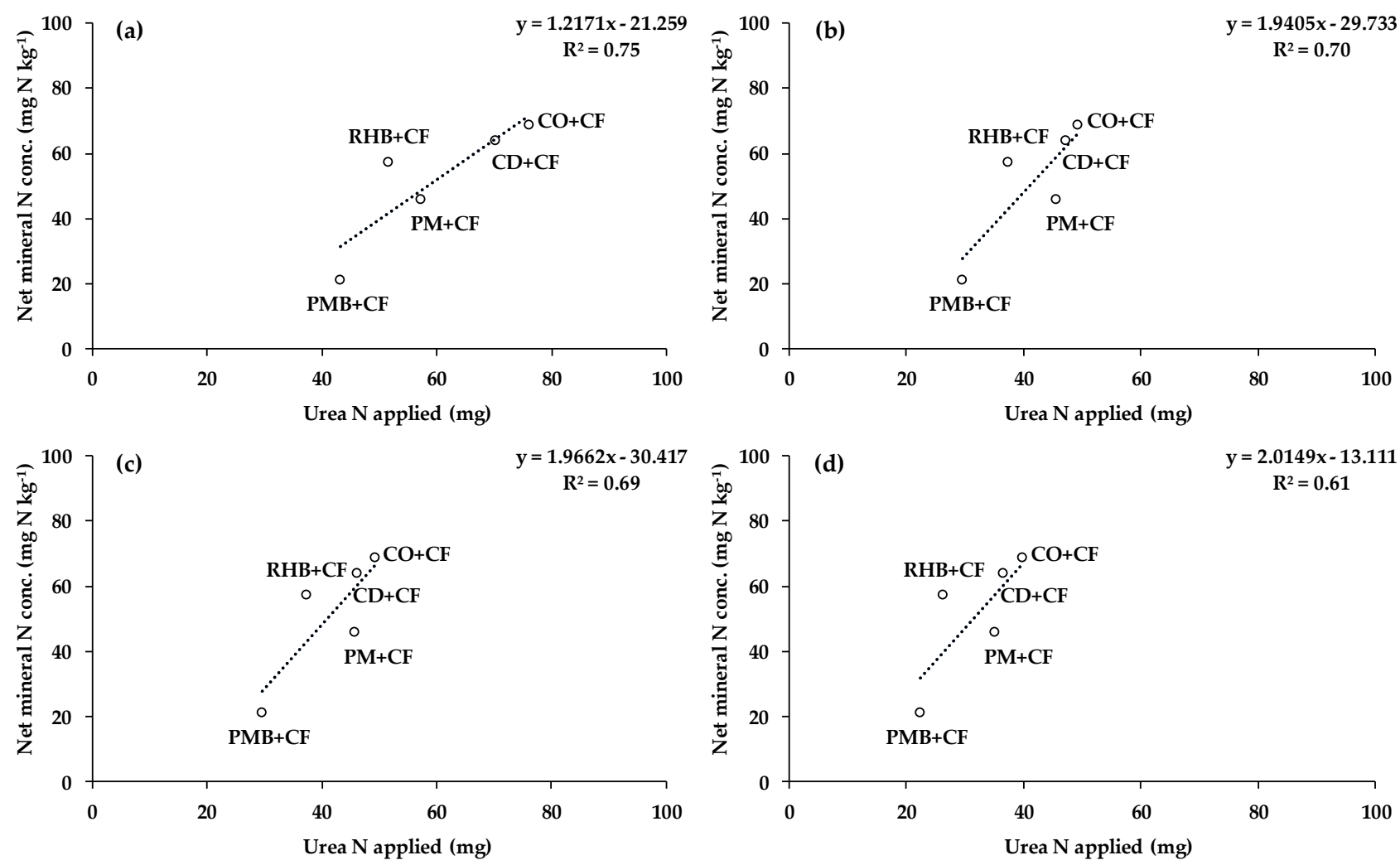

Figure 3. Correlation between net mineral $\mathrm{N}$ conc. and urea $\mathrm{N}$ application in (a) acidic soil with FC; (b) acidic soil with CSW; (c) charland soil with FC; and (d) charland soil with CSW. 


\section{Discussion}

\subsection{Influence of Soil Type on $N$ Dynamics and Changes in Soil $p H$}

In acid soil, $\mathrm{NH}_{4}{ }^{+}-\mathrm{N}$ was substantially greater than in charland soil. This is attributed to the higher $\mathrm{NH}_{4}{ }^{+}$production in acidic soil and increased gaseous $\mathrm{N}$ loss (Table 7) in charland soil as a result of the higher soil $\mathrm{pH}$ and low clay content [48]. Higher organic matter as well as clay content in the acidic soil adsorb more positive $\mathrm{NH}_{4}{ }^{+}$ions, resulting in less gaseous $\mathrm{N}$ loss. The higher $\mathrm{pH}$ of charland soil also favors urease activity and ammonia volatilization [49]. In acidic soil, $\mathrm{NO}_{3}{ }^{-}-\mathrm{N}$ levels were much greater than in charland soil. This might be due to the rapid nitrification of the available $\mathrm{NH}_{4}{ }^{+}-\mathrm{N}$ in acidic soil. Although it is stated that soil bacteria work effectively under neutral conditions, our results suggest that soil $\mathrm{pH}$ doesn't affect the function of soil bacteria in the acidic soil. Nitrifying bacteria typically function in soil with a $\mathrm{pH}$ ranging from 5.5 to around 10.0, with an optimum around 8.5 [50]. Furthermore, nitrification has even been observed in soils with $\mathrm{pH}$ levels as low as 3.8 [51]. $\mathrm{N}$ release through mineralization of organic amendments was only observed in the case of acidic soil, which resulted in more mineral $\mathrm{N}$ concentration in acidic soil. Mineralization potential $\left(\mathrm{N}_{0}\right)$ and rate constant was substantially higher in acidic soil than in charland soil due to its high organic matter content, clay content, TN content and low $\mathrm{pH}$, which help to adsorb more $\mathrm{NH}_{4}{ }^{+}$and reduce gaseous losses. Canali et al. [52] found that the potential for $\mathrm{N}$ release in clay textured soil was substantially higher (9\%) than in silty-clay textured soil. Low N release can lead to a lot of STN retention [53]. As $\mathrm{N}$ release is a microbiological process, STN retention is influenced by the organic matter content of the soil. More STN was retained in charland soil because of its low organic matter content than in acidic soil which indicated lower microbial activity and mineralization. With increasing clay content, several researchers observed lower mineralization and an increased tendency to immobilize [17,54]. Hadas as al. [55] found no significant differences in net mineralization in sandy and clay soils incubated with dairy and poultry manure, but Canali et al. [52] found higher $\mathrm{N}$ mineralization ( $9 \%$ ) in clay textured soil than clay loam textured soil. At the end of 120 days of incubation, the change in soil $\mathrm{pH}$ in different treatments ranged from -0.44 to 0.87 units in acidic soil, whereas the range was -0.32 to 0.62 units in charland soil. The higher absolute change in the magnitude of acidic soil than in charland soil may be due to the low initial pH of acidic soil than in charland soil [56]. High organic matter content of acidic soil results in increased buffering capacity and cation exchange capacity (CEC) of soil which adsorbs more $\mathrm{H}^{+}$and acidic cations that causes increased soil $\mathrm{pH}[56]$.

\subsection{Influence of Soil Moisture on N Dynamics and Changes in Soil $p H$}

Our results revealed that $\mathrm{NH}_{4}{ }^{+}-\mathrm{N}$ was found to be the dominating form of $\mathrm{N}$ under CSW conditions compared to FC conditions, as submergence increased $\mathrm{NH}_{4}{ }^{+}-\mathrm{N}$ concentration [57], which is in line with Haque et al. [35] and Calderon et al. [58]. Under CSW conditions, there is insufficient $\mathrm{O}_{2}$ to complete the nitrification process and $\mathrm{N}$ mineralization ends at the ammonification stage, resulting in higher $\mathrm{NH}_{4}{ }^{+}-\mathrm{N}$ content under CSW [59]. Aeration (oxygen), low soil moisture condition, and greater quantity of ammonium ions are the most critical environmental requirements for the nitrification process in soil [60]. In the soil system, soil moisture and aeration, or soil oxygen levels, are inversely related. Because water fills most pore spaces, increased soil moisture reduces oxygen content in the soil, and it also hinders atmospheric air diffusion into the soil. As a result, $\mathrm{NO}_{3}{ }^{-}-\mathrm{N}$ concentration was higher under FC conditions. Mineral N concentration was higher in FC conditions than in CSW conditions. This is attributed to the mineralization of organic amendments under FC conditions and immobilization of urea N under CSW conditions. FC condition is more favourable for mineralization of organic amendments and $\mathrm{N}$ release [35]. Ammonia volatilization and denitrification are the significant $\mathrm{N}$ loss pathways under CSW condition [61]. 40.4\% more gaseous loss under CSW condition is another reason for higher mineral N concentration under FC conditions. Mineralization potential and rate constant was also higher in FC conditions due to more mineral $\mathrm{N}$ production and less 
gaseous $\mathrm{N}$ loss. As $\mathrm{N}$ mineralization happened more quickly under FC than under CSW, more total $\mathrm{N}$ retained under CSW moisture conditions, as previously observed by Islam et al. [46,62], Haque et al. [35] and Rahman et al. [36]. Our findings showed that when soil was incubated at FC conditions, the $\mathrm{pH}$ dropped sharply with time compared to the initial condition. However, when soil was incubated at CSW conditions, the opposite scenario was found, as previously reported by Zarate-Valdez et al. [63]. Under CSW conditions, consumption of protons during the reduction of oxidants and mineralization process as well as denitrification increased soil $\mathrm{pH}$, however, under FC conditions, fast nitrification reduced soil $\mathrm{pH}$ by releasing many protons [64].

\subsection{Influence of Treatments and C:N Ratio on $N$ Dynamics and Changes in Soil $p H$}

In both soil types and moisture regimes, $\mathrm{CO}+\mathrm{CF}$ and $\mathrm{CD}+\mathrm{CF}$ exhibited the greatest release of $\mathrm{NH}_{4}{ }^{+}-\mathrm{N}$ because the combinations included a higher quantity of urea $\mathrm{N}$. Urea application increases urease activity in soil and possesses a positive linear relationship with the $\mathrm{N}$ application rate [65]. The fast hydrolysis of urea fertilizer occurs owing to a favourable urease activity environment, which also promoted the breakdown of $\mathrm{CO}$ and $\mathrm{CD}$, resulting in increased $\mathrm{NH}_{4}{ }^{+}-\mathrm{N}$ in all instances. The two biochar treatments PMB and $\mathrm{RHB}$ responded contrasting to each other. The mineralization of PMB was observed in all the cases whereas mineralization of RHB was observed only in acidic soil kept under FC conditions. The results suggest that PMB contained more labile $\mathrm{N}$ pool which resulted in a higher $\mathrm{N}$ mineralization, whereas RHB contained more recalcitrant components resulting in net immobilization [66,67]. Although biochar had a higher $\mathrm{N}$ content, the lowest mineral $\mathrm{NH}_{4}{ }^{+}-\mathrm{N}$ was reported in the biochar treatment combinations because biochar is more stable and less susceptible to mineralization [68]. N-enriched biochar like PMB, on the other hand, may acts as a slow-release nitrogen fertilizer [69]. The buildup of $\mathrm{NO}_{3}{ }^{-}-\mathrm{N}$ was considerably greater in $\mathrm{CO}+\mathrm{CF}$ compared to $\mathrm{CD}+\mathrm{CF}$ and $\mathrm{PM}+\mathrm{CF}$. This occurred as a result of the greater amount of $\mathrm{NH}_{4}{ }^{+}$production which underwent rapid nitrification.

The amount of nitrogen released by organic additions is determined by the chemical compositions of the organic components (e.g., $\mathrm{N}$ content, $\mathrm{C}: \mathrm{N}$ ratio, and contents of cellulose and hemicelluloses, lignin, and polyphenols) [70,71], application rate of manures [35] and on the properties of soil microorganisms [72]. Organic amendments with high nitrogen content and low C:N ratios provide more mineral $\mathrm{N}$ due to mineralization [73]. In OAs with lower $\mathrm{N}$ levels and greater $\mathrm{C}: \mathrm{N}$ ratios, however, $\mathrm{N}$ can be immobilized [72]. The organic materials used in our study have low C:N ratio and high $\mathrm{N}$ content which led to mineralization of organic $\mathrm{N}$ in case of PM and PMB as well as all treatments in acidic soil kept under FC conditions. Several authors reported the N release by $64-91 \%$ from farmyard manure, dhaincha and legume residues [36]; 64-83\% from cowdung, poultry manure, cowdung slurry and poultry manure slurry [35] which supports our results of $\mathrm{N}$ release that ranged from 25 to $76 \%$ of input depending on the soil type, moisture status and organic amendments. After 120 days, STN was still higher than the initial unamended soil. The lower C:N ratio of the soil amendments boosts up the mineralization process, resulting in decrease in STN concentration after 120 days compared to the initial STN concentration [74].

The principal causes of soil $\mathrm{pH}$ change during the incubation period are hydrolysis of urea, $\mathrm{N}$ mineralization from soil and organic sources and subsequent $\mathrm{NH}_{4}{ }^{+}$nitrification [75]. Liming properties of organic manures are widely known [76]. Except for biochar, all treatments significantly enhanced soil $\mathrm{pH}$ in the CSW conditions compared to the control, but decreased soil $\mathrm{pH}$ in the FC conditions. The higher $\mathrm{pH}$ of the $\mathrm{CO}, \mathrm{PM}$ and $\mathrm{CD}$ compared to the initial $\mathrm{pH}$ of both soils is the primary reason of increased soil $\mathrm{pH}$ under CSW conditions. Organic amendments enhance soil organic matter content which results in increased buffering capacity and CEC of soil adding to the increase of soil $\mathrm{pH}$ under CSW conditions [77]. Besides, dissociation of alkaline products which are present in the composition of the animals' diet, the metabolic activities of organic compounds, and protein degradation, which liberates ammonia into the environment [78], as well as the use of 
calcium oxide during poultry house disinfection [79] may be the reasons of increased soil $\mathrm{pH}$. However, mineralization of $\mathrm{CO}, \mathrm{PM}$, and CD under FC conditions releases proton which decreases the soil $\mathrm{pH}$. Biochar raised soil $\mathrm{pH}$ in any soil and moisture conditions, as previously documented by various authors in long-term incubation trials, confirming our findings $[80,81]$. The high $\mathrm{pH}$ of RHB and PMB, which is primarily owing to the biochar being dominated by alkaline carbonates, alkali earth metals, and organic anions, may be causing the $\mathrm{pH}$ increase in the soil [82]. The high surface area and porous nature of biochar resulting in higher CEC of biochar-amended soils could be another explanation for an increase in soil $\mathrm{pH}$. However, the addition of biochar to the soil raised the $\mathrm{pH}$ as a result of proton consumption processes [83].

\section{Conclusions}

The results of the study showed that $\mathrm{N}$ release was higher in acidic soil and FC moisture status. The CO, CD, and PM based IPNS treatments had higher potential for $\mathrm{N}$ supply in acidic soils under FC moisture status. Mineral N release reached its peak at seven days of application and remained more or less constant at FC but decreased thereafter due to loss of $\mathrm{N}$ in different pathways, particularly volatilization and denitrification, indicating that chemical fertilizer should be applied at least seven days prior to plants' $\mathrm{N}$ requirement. The maximum mineral N released from IPNS treatments varied between $24.90-76.29 \%$ of input depending on the soil type and moisture status. PM and PMB mineralized in all soil and moisture conditions but immobilization of urea $\mathrm{N}$ was observed in $\mathrm{CO}+\mathrm{CF}, \mathrm{RHB}+\mathrm{CF}$ and $\mathrm{CD}+\mathrm{CF}$ in all the cases except for acidic soil with FC conditions. Gaseous N loss was higher in charland soil than in acidic soil and PMB based IPNS had the lowest gaseous $\mathrm{N}$ loss. $\mathrm{N}$ mineralization was strongly correlated with urea $\mathrm{N}$ application. The results revealed that CO, CD, and PM based IPNS approaches can be suggested for both acid and charland soils in terms of $\mathrm{N}$ release to the crops in a single season. Besides, PMB with recommended chemical fertilizer (not IPNS basis) can be a good option for N supply to the crops. Biochars uplift the $\mathrm{pH}$ towards the neutral condition in both soils and moisture regimes, which will help to increase the availability of nutrients, especially $\mathrm{P}$.

Supplementary Materials: The following are available online at https:/ /www.mdpi.com/article/10 .3390 /agronomy11112163/s1, Figure S1. Change in soil total N in (a) acidic soil with FC; (b) acidic soil with CSW; (c) charland soil with FC; and (d) charland soil with CSW after addition of different IPNS treatments during the 120 days of incubation; Figure S2. Trend of changes in soil pH in (a) acidic soil with FC; (b) acidic soil with CSW; (c) charland soil with FC; and (d) charland soil with CSW after addition of organic amendments during the 120 days of incubation period.

Author Contributions: Conceptualization, S.U., M.R.I. and M.M.R.J.; methodology, S.U., M.R.I., M.M.R.J. and M.M.R. (Mohammad Mojibur Rahman); software, S.U. and A.F.A.; validation, S.U., M.R.I. and M.M.R.J.; formal analysis, S.U.; investigation, S.U., M.R.I., M.M.R.J. and M.M.R. (Mohammad Mojibur Rahman); resources, M.R.I. and M.M.R.J.; data curation, S.U., M.R.I. and M.M.R.J.; writing—original draft preparation, S.U., M.R.I. and M.M.R.J.; writing—review and editing, S.U., M.R.I., M.M.R.J., M.M.R. (Mohammad Mojibur Rahman), S.H., M.M.H., A.A.A.-S., A.F.A. and M.M.R. (Mohammad Mahmudur Rahman); visualization, S.U., M.R.I. and A.F.A.; supervision, M.R.I. and M.M.R.J.; project administration, M.R.I. and M.M.R.J.; funding acquisition, M.R.I., M.M.R.J., S.H., M.M.H. and A.A.A.-S. All authors have read and agreed to the published version of the manuscript.

Funding: This research was funded by the World Bank under National Agricultural Technology Program- Phase II Project (NATP-2) administered by Bangladesh Agricultural Research Council (BARC) (Project ID: 135). The current work was partially funded by Taif University Researchers Supporting Project number (TURSP-2020/142), Taif University, Taif, Saudi Arabia.

Institutional Review Board Statement: Not applicable.

Informed Consent Statement: Not applicable.

Data Availability Statement: The raw data supporting the conclusions of this article will be made available by the authors, without undue reservation. 
Acknowledgments: The authors acknowledge the partial support by the World Bank under National Agricultural Technology Program- Phase II Project (NATP-2) administered by Bangladesh Agricultural Research Council (BARC) (Project ID: 135). The authors extend their appreciation to Taif University for funding current work by Taif University Researchers Supporting Project number (TURSP-2020/142), Taif University, Taif, Saudi Arabia.

Conflicts of Interest: The authors declare that the research was conducted in the absence of any commercial or financial relationships that could be construed as a potential conflict of interest.

\section{References}

1. FRG. Fertilizer Recommendation Guide; Bangladesh Agricultural Research Council: Dhaka, Bangladesh, 2018.

2. Satter, S.A.; Islam, M.N. Charlands of Bangladesh: Their extent, management and future research needs. In Proceedings of the Soil Fertility, Fertilizer Management and Future Strategy, Farmgate, Dhaka, 18-19 January 2010; pp. 1-9.

3. Diacono, M.; Montemurro, F. Long term effects of organic amendments on soil fertility: A review. Agron. Sustain. Dev. 2010, 30, 401-422. [CrossRef]

4. Fageria, N.K. Soil fertility and plant nutrition research under field conditions: Basic principles and methodology. J. Plant Nut. 2007, 30, 203-223. [CrossRef]

5. Kumar, M.; Baishaya, L.K.; Ghosh, D.C.; Gupta, V.K.; Dubey, S.K.; Das, A.; Patel, D.P. Productivity and soil health of potato (Solanum tuberosum L.) field as influenced by organic manures, inorganic fertilizers and biofertilizers under high altitudes of Eastern Himalayas. J. Agric. Sci. 2012, 4, 223-234. [CrossRef]

6. Jeptoo, A.; Aguyoh, J.N.; Saidi, M. Improving Carrot Yield and Quality through the Use of Bio-Slurry Manure. Sustain. Agric. Res. 2013, 2, 164-172. [CrossRef]

7. Islam, M.R.; Rashid, M.B.; Siddique, A.B.; Afroz, H. Integrated effects of manures and fertilizers on the yield and nutrient uptake by BRRI dhan49. J. Bangladesh Agril. Univ. 2014, 12, 67-72. [CrossRef]

8. Nuruzzaman, M.; Ashrafuzzaman, M.; Islam, M.Z.; Islam, M.R. Field efficiency of biofertilizers on the growth of okra (Abelmoschus esculentus [(L.) Moench]). J. Plant Nutr. Soil Sci. 2003, 166, 764-770. [CrossRef]

9. Abid, M.; Batool, T.; Siddique, G.; Ali, S.; Binyamin, R.; Shahid, M.J.; Rizwan, M.; Alsahli, A.A.; Alyemeni, M.N. Integrated Nutrient Management Enhances Soil Quality and Crop Productivity in Maize-Based Cropping System. Sustainability 2020, 12, 10214. [CrossRef]

10. Nweke, I.A.; Nsoanya, L.N. Effect of Cow Dung and Urea Fertilization on Soil Properties, Growth, and Yield of Cucumber (Cucumis sativus L.). J. Agric. Ecol. Res. Int. 2015, 3, 81-88. [CrossRef]

11. Kulczycki, G.; Magnucka, E.G.; Oksińska, M.P.; Kucińska, J.; Kobyłecki, R.; Paweska, K.; Zarzycki, R.; Kacprzak, A.; Pietr, S.J The Effect of Various Types of Biochar Mixed with Mineral Fertilization on the Development and Ionome of Winter Wheat (Triticum aestivum L.) Seedlings and Soil Properties in a Pot Experiment. Agronomy 2020, 10, 1903. [CrossRef]

12. Schaller, J.; Wang, J.; Islam, M.R.; Planer-Friedrich, B. Black carbon yields highest nutrient and lowest arsenic release when using rice residuals in paddy soils. Sci. Rep. 2018, 8, 17004. [CrossRef] [PubMed]

13. Grossman, J.M.; O’Neill, B.E.; Tsai, S.M.; Liang, B.; Neves, E.; Lehmann, J.; Thies, J.E. Amazonian anthrosols support similar microbial communities that differ distinctly from those extant in adjacent, unmodified soils of the same mineralogy. Microb. Ecol. 2010, 60, 192-205. [CrossRef] [PubMed]

14. Gruber, N.; Galloway, J.N. An Earth-system perspective of the global nitrogen cycle. Nature 2008, 451, 293-296. [CrossRef] [PubMed]

15. Ouyang, W.; Shan, Y.S.; Hao, F.H.; Chen, S.Y.; Pu, X.; Wang, M.K. The effect on soil nutrients resulting from land use transformations in a freeze-thaw agricultural ecosystem. Soil Till. Res. 2013, 132, 30-38. [CrossRef]

16. Masunga, R.H.; Uzokwe, V.N.; Mlay, P.D.; Odeh, I.; Singh, A.; Buchan, D.; De Neve, S. Nitrogen mineralization dynamics of different valuable organic amendments commonly used in agriculture. Appl. Soil Ecol. 2016, 101, 185-193. [CrossRef]

17. Cassity-Duffey, K.; Cabrera, M.; Franklin, D.; Gaskin, J.; Kissel, D. Effect of soil texture on nitrogen mineralization from organic fertilizers in four common southeastern soils. Soil Sci. Soc. Am. J. 2020, 84, 534-542. [CrossRef]

18. Dessureault-Rompré, J.; Zebarth, B.J.; Burton, D.L.; Georgallas, A. Predicting soil nitrogen supply from soil properties. Can. J. Soil Sci. 2015, 95, 63-75. [CrossRef]

19. Wade, J.; Horwath, W.R.; Burger, M.B. Integrating soil biological and chemical indices to predict net nitrogen mineralization across California agricultural systems. Soil Sci. Soc. Am. J. 2016, 80, 1675-1687. [CrossRef]

20. Pramanik, P.; Safique, S.; Zahan, A.; Phukan, M.; Ghosh, S. Cellulolytic microorganisms control the availability of nitrogen in microcosm of shredded pruning litter treated highly acidic tea-growing soils of Assam in Northeast India. Appl. Soil Ecol. 2017, 120, 30-34. [CrossRef]

21. Waldrop, M.P.; Holloway, M.J.; Smith, D.B.; Goldhaber, M.B.; Drenovsky, R.E.; Scow, K.M.; Dick, R.; Howard, D.; Wylie, B.; Grace, J.B. The interacting roles of climate, soils, and plant production on soil microbial communities at a continental scale. Ecology 2017, 98, 1957-1967. [CrossRef]

22. Lehmann, J.; Joseph, S. Biochar for environmental management: An introduction. In Biochar for Environmental Management, Science and Technology; Lehmann, J., Joseph, S., Eds.; Earthscan: London, UK, 2009; pp. 1-12. 
23. Ulyett, J.; Sakrabani, R.; Kibblewhite, M.; Hann, M. Impact of biochar addition on water retention, nitrification and carbon dioxide evolution from two sandy loam soils. Eur. J. Soil Sci. 2014, 65, 96-104. [CrossRef]

24. Case, S.D.C.; McNamara, N.P.; Reay, D.S.; Stott, A.W.; Grant, H.K.; Whitaker, J. Biochar suppresses $\mathrm{N}_{2} \mathrm{O}$ emissions while maintaining $\mathrm{N}$ availability in a sandy loam soil. Soil Biol. Biochem. 2015, 81, 178-185. [CrossRef]

25. Mandal, S.; Thangarajan, R.; Bolan, N.S.; Sarkar, B.; Khan, N.; Ok, Y.S.; Naidu, R. Biochar-induced concomitant decrease in ammonia volatilization and increase in nitrogen use efficiency by wheat. Chemosphere 2016, 142, 120-127. [CrossRef] [PubMed]

26. Zheng, H.; Wang, Z.Y.; Deng, X.; Zhao, J.; Luo, Y.; Novak, J.; Herbert, S.; Xing, B.S. Characteristics and nutrient values of biochars produced from giant reed at different temperatures. Bioresour. Technol. 2013, 130, 463-471. [CrossRef]

27. Bass, A.M.; Bird, M.I.; Kay, G.; Muirhead, B. Soil properties, greenhouse gas emissions and crop yield under compost, biochar and co-composted biochar in two tropical agronomic systems. Sci. Total Environ. 2016, 550, 459-470. [CrossRef]

28. Ameloot, N.; Sleutel, S.; Das, K.C.; Kanagaratnam, J.; de Neve, S. Biochar amendment to soils with contrasting organic matter level: Effects on N mineralization and biological soil properties. GCB Bioen. 2015, 7, 135-144. [CrossRef]

29. Maestrini, B.; Herrmann, A.M.; Nannipieri, P.; Schmidt, M.W.I.; Abiven, S. Ryegrass-derived pyrogenic organic matter changes organic carbon and nitrogen mineralization in a temperate forest soil. Soil Biol. Biochem. 2014, 69, 291-301. [CrossRef]

30. Dempster, D.N.; Jones, D.L.; Murphy, D.V. Organic nitrogen mineralisation in two contrasting agro-ecosystems is unchanged by biochar addition. Soil Biol. Biochem. 2012, 48, 47-50. [CrossRef]

31. Prayogo, C.; Jones, J.; Baeyens, J.; Bending, G. Impact of biochar on mineralisation of $\mathrm{C}$ and $\mathrm{N}$ from soil and willow litter and its relationship with microbial community biomass and structure. Biol. Fertil. Soils 2013, 50, 695-702. [CrossRef]

32. Dempster, D.N.; Gleeson, D.B.; Solaiman, Z.M.; Jones, D.L.; Murphy, D.V. Decreased soil microbial biomass and nitrogen mineralisation with Eucalyptus biochar addition to a coarse textured soil. Plant Soil 2012, 354, 311-324. [CrossRef]

33. Wang, C.; Wan, S.; Xing, X.; Zhang, L.; Han, X. Temperature and soil moisture interactively affected soil net $\mathrm{N}$ mineralization in temperate grassland in Northern China. Soil Biol. Biochem. 2006, 38, 1101-1110. [CrossRef]

34. Curtin, D.; Beare, M.H.; Hernandez-Ramirez, G. Temperature and moisture effects on microbial biomass and soil organic matter mineralization. Soil Sci. Soc. Am. J. 2012, 76, 2055-2067. [CrossRef]

35. Haque, M.A.; Jahiruddin, M.; Rahman, M.M.; Saleque, M.A. Nitrogen mineralization of bioslurry and other manures in soil. Res. Agric. Livest. Fish. 2015, 2, 221-228. [CrossRef]

36. Rahman, M.H.; Islam, M.R.; Jahiruddin, M.; Rafii, M.Y.; Hanafi, M.M.; Malek, M.A. Integrated nutrient management in maizelegume-rice cropping pattern and its impact on soil fertility. J. Food Agric. Environ. 2013, 11, 648-652.

37. Guntiñas, M.E.; Leirós, M.C.; Trasar-Cepeda, C.; Gil-Sotres, F. Effects of moisture and temperature on net soil nitrogen mineralization: A laboratory study. Eur. J. Soil Biol. 2012, 48, 73-80. [CrossRef]

38. Ono, S. Nitrogen mineralization from paddy and upland soils under flooded and non-flooded incubation. Soil Sci. Plant Nutr. 1989, 35, 417-426. [CrossRef]

39. Abbasi, M.K.; Munazza, H.; Khalique, A.; Khan, S.R. Mineralization of three organic manures used as nitrogen source in a soil incubated under laboratory conditions. Commun. Soil Sci. Plant Anal. 2007, 38, 1691-1711. [CrossRef]

40. Jahangir, M.M.R.; Islam, S.; Nitu, T.T.; Uddin, S.; Kabir, A.K.M.A.; Meah, M.B.; Islam, R. Bio-Compost-Based Integrated Soil Fertility Management Improves Post-Harvest Soil Structural and Elemental Quality in a Two-Year Conservation Agriculture Practice. Agronomy 2021, 11, 2101. [CrossRef]

41. Moharana, P.C.; Biswas, D.R.; Datta, S.C. Mineralization of Nitrogen, Phosphorus and Sulphur in Soil as Influenced by Rock Phosphate Enriched Compost and Chemical Fertilizers. J. Indian Soc. Soil Sci. 2015, 63, 283-293. [CrossRef]

42. FAO and UNDP. Land Resources Appraisal of Bangladesh for Agricultural Development; Report 2; Agro-Ecological Regions of Bangladesh, Food and Agriculture Organization: Rome, Italy, 1988; pp. 212-221.

43. Keeney, D.R.; Nelson, D.W. Nitrogen-Inorganic Forms. In Methods of Soil Analysis, Part 2, 2nd ed.; Agronomy 9; ASA and SSSA: Madison, WI, USA, 1982; p. 643.

44. Bremner, J.M.; Mulvaney, C.S. Nitrogen-Total. In Methods of Soil Analysis. Part 2. Chemical and Microbiological Properties; Page, A.L., Miller, R.H., Keeney, D.R., Eds.; American Society of Agronomy, Soil Science Society of America: Madison, WI, USA, 1982; pp. 595-624.

45. Peech, M. Hydrogen-ion activity. In Methods of Soil Analysis: Part 2 Chemical and Microbiological Properties; American Society of Agronomy, Soil Science Society of America: Madison, WI, USA, 1965; Volume 9, pp. 914-926.

46. Islam, M.R.; Bilkis, S.; Hoque, T.S.; Uddin, S.; Jahiruddin, M.; Rahman, M.M.; Rahman, M.M.; Alhomrani, M.; Gaber, A.; Hossain, M.A. Mineralization of Farm Manures and Slurries for Successive Release of Carbon and Nitrogen in Incubated Soils Varying in Moisture Status under Controlled Laboratory Conditions. Agriculture 2021, 11, 846. [CrossRef]

47. Sihag, D.; Singh, J.P. Effect of temperature and soil moisture regime on green manure N mineralization in clay loam soil. J. Indian Soc. Soil Sci. 1999, 47, 212-217.

48. Zhenghu, D.; Honglang, X. Effects of Soil Properties on Ammonia Volatilization. Soil Sci. Plant Nutr. 2000, 46, 845-852. [CrossRef]

49. Sommer, S.G.; Schjoerring, J.K.; Denmead, O.T. Ammonia Emission from Mineral Fertilizers and Fertilized Crops. Adv. Agron. 2004, 82, 557-622.

50. Sahrawat, K.L. Factors Affecting Nitrification in Soils. Commun. Soil Sci. Plant Anal. 2008, 39, 1436-1446. [CrossRef]

51. Tisdale, S.L.; Nelson, W.L. Soil Fertility and Fertilizers, 2nd ed.; The Macmillan Co.: New York, NY, USA, 1970. 
52. Canali, S.; Di Bartolomeo, E.; Tittarelli, F.; Montemurro, F.; Verrastro, V.; Ferri, D. Comparison of different laboratory incubation procedures to evaluate nitrogen mineralization in soils amended with aerobic and anaerobic stabilized organic materials. J. Food Agric. Environ. 2011, 9, 540-546.

53. Abbasi, M.K.; Khaliq, A. Nitrogen Mineralization of a Loam Soil Supplemented with Organic-Inorganic Amendments under Laboratory Incubation. Front. Plant Sci. 2016, 7, 1038. [CrossRef]

54. Stadler, C.; con Tucher, S.; Schmidhalter, U.; Gutser, R.; Heuwinkel, H. Nitrogen release from plant-derived and industrially processed organic fertilizers used in organic horticulture. J. Plant Nutr. Soil Sci. 2006, 1, 69549-69556. [CrossRef]

55. Hadas, A.; Bar-Yosef, B.; Davidov, S.; Sofer, M. Effect of pelleting, temperature, and soil type on mineral nitrogen release from poultry and dairy manures. Soil Sci. Soc. Am. J. 1983, 47, 1129-1133. [CrossRef]

56. Ghorbani, M.; Asadi, H.; Abrishamkesh, S. Effects of rice husk biochar on selected soil properties and nitrate leaching in loamy sand and clay soil. Int. Soil Water Conserv. Res. 2019, 7, 258-265. [CrossRef]

57. Duhan, B.S.; Devender, K.; Singh, J.P.; Kuhad, M.S.; Dahiya, S.S. Effect of nitrogen, farmyard manure and metribuzin on nitrogen transformation. J. Indian Soc. Soil Sci. 2005, 53, 184-187.

58. Calderon, F.J.; McCarty, G.W.; Van Kassel, J.A.; Reeves, J.B. 2004: Carbon and Nitrogen dynamic during incubation of manured soil. Soil Sci. Soc. Am. J. 2004, 68, 1592-1599. [CrossRef]

59. Brady, N.C.; Weil, R.C. The Nature and Properties of Soils, 14th ed.; (Revised); Dorling Kindersley (India) Pvt. Ltd., licensees of Pearson Education in Asia: Noida, India, 2012; pp. 513-517.

60. Allen, S.C.; Jose, S.; Nair, P.K.R.; Brecke, B.J.; Nair, V.D.; Graetz, D.A.; Ramsey, C.L. Nitrogen mineralization in a pecan (Carya illinoensis K. Koch)-cotton (Gossypium hirsutum L.) alley cropping system in the southern United States. Biol. Fert. Soils 2005, 41, 28-37. [CrossRef]

61. Uddin, S.; Nitu, T.T.; Milu, U.M.; Nasreen, S.S.; Hossenuzzaman, M.; Haque, M.E.; Hossain, B.; Jahiruddin, M.; Bell, R.W.; Müller C.; et al. Ammonia fluxes and emission factors under an intensively managed wetland rice ecosystem. Environ. Sci. Process. Impacts 2021, 23, 132-143. [CrossRef]

62. Islam, M.R.; Bilkis, S.; Hoque, T.S.; Uddin, S.; Jahiruddin, M.; Rahman, M.M.; Siddique, A.B.; Hossain, M.A.; Danso Marfo, T.; Danish, S.; et al. Mineralization of Farm Manures and Slurries under Aerobic and Anaerobic Conditions for Subsequent Release of Phosphorus and Sulphur in Soil. Sustainability 2021, 13, 8605. [CrossRef]

63. Zarate-Valdez, J.L.; Zasoski, R.J.; Läuchli, A.E. Short-term effects of moisture content on soil solution pH and soil Eh. Soil Sci. 2006, 171, 423-431.

64. Shi, R.Y.; Ni, N.; Nkoh, J.N.; Li, J.Y.; Xu, R.K.; Qian, W. Beneficial dual role of biochars in inhibiting soil acidification resulting from nitrification. Chemosphere 2019, 234, 43-51. [CrossRef]

65. Jahangir, M.M.R.; Nitu, T.T.; Uddin, S.; Siddaka, A.; Sarker, P.; Khan, S.; Jahiruddin, M.; Müller, C. Carbon and nitrogen accumulation in soils under conservation agriculture practices decreases with nitrogen application rates. Appl. Soil Ecol. 2021, 168, 104178. [CrossRef]

66. Clough, T.; Condron, L.; Kammann, C.; Müller, C. A review of biochar and soil nitrogen dynamics. Agronomy 2013, 3, 275-293. [CrossRef]

67. Wang, T.; Camps Arbestain, M.; Hedley, M.; Bishop, P. Chemical and bioassay characterisation of nitrogen availability in biochar produced from dairy manure and biosolids. Org. Geochem. 2012, 51, 45-54. [CrossRef]

68. Lehmann, J.; Rillig, M.C.; Thies, J.; Masiello, C.A.; Hockaday, W.C.; Crowley, D. Biochar effects on soil biota-a review. Soil Biol. Biochem. 2011, 43, 1812-1836. [CrossRef]

69. Sarkhot, D.V.; Berhe, A.A.; Ghezzehei, T.A. Impact of biochar enriched with dairy manure effluent on carbon and nitrogen dynamics. J. Environ. Qual. 2012, 41, 1107-1114. [CrossRef]

70. Calderón, F.J.; McCarty, G.W.; Reeves, J.B. Analysis of manure and soil nitrogen mineralization during incubation. Biol. Fert. Soils 2005, 41, 328-336. [CrossRef]

71. Mohanty, M.; Reddy, S.K.; Probert, M.E.; Dalal, R.C.; Rao, S.A.; Menzies, N.W. Modelling N mineralization from green manure and farmyard manure from a laboratory incubation study. Ecol. Modelling 2011, 222, 719-726. [CrossRef]

72. Manojlović, M.; Čabilovski, R.; Bavec, M. Organic materials: Sources of nitrogen in the organic production of lettuce. Turk. J. Agric. For. 2010, 34, 163-172.

73. Cordovil, C.M.D.S.; Coutinho, J.; Goss, M.; Cabral, F. Potentially mineralizable nitrogen from organic materials applied to a sandy soil: Fitting the one-pool exponential model. Soil Use Manag. 2005, 21, 65-72. [CrossRef]

74. Tong, C.; Xiao, H.; Tang, G.; Wang, H.; Huang, T.; Xia, H.; Keith, S.J.; Li, Y.; Liu, S.; Wu, J. Long-term fertilizer effects on organic carbon and total nitrogen and coupling relationships of $\mathrm{C}$ and $\mathrm{N}$ in paddy soils in subtropical China. Soil Till. Res. 2009, 106, 8-14. [CrossRef]

75. Yuan, J.H.; Xu, R.K.; Qian, W.; Wang, R.H. Comparison of the ameliorating effects on an acidic Ultisol between four crop straws and their biochars. J. Soils Sediments 2011, 11, 741-750. [CrossRef]

76. Manna, M.C.; Swarup, A.; Wanjari, R.H.; Mishra, B.; Shahi, D.K. Long-term fertilization, manure and liming effects on soil organic matter and crop yields. Soil Till. Res. 2007, 94, 397-409. [CrossRef]

77. Adekiya, A.O.; Agbede, T.M.; Ejue, W.S.; Aboyeji, C.M.; Dunsin, O.; Aremu, C.O.; Owolabi, A.O.; Ajiboye, B.O.; Okunlola, O.F.; Adesola, O.O. Biochar, poultry manure and NPK fertilizer: Sole and combine application effects on soil properties and ginger (Zingiber officinale Roscoe) performance in a tropical Alfisol. Open Agric. 2020, 5, 30-39. [CrossRef] 
78. Mushtaq, M.; Iqbal, M.K.; Khalid, A.; Khan, R.A. Humification of poultry waste and rice husk using additives and its application. Int. J. Recycl. Org. Waste Agric. 2019, 8, 15-22. [CrossRef]

79. Wolf, J.; de Gouvea, A.; da Silva, E.R.L.; Potrich, M.; Appel, A. Métodos físicos e cal hidratada para manejo do cascudinho dos aviários. Ciencia Rural. 2014, 44, 161-166. [CrossRef]

80. Masud, M.M.; Baquyb, M.A.; Akhtera, S.; Sena, R.; Barmana, A.; Khatun, M.R. Liming effects of poultry litter derived biochar on soil acidity amelioration and maize growth. Ecotoxicol. Environ. Saf. 2020, 202, 110865. [CrossRef] [PubMed]

81. Kamran, M.A.; Jiang, J.; Li, J.Y.; Shi, R.Y.; Mehmood, K.; Baquy, M.A.A.; Xu, R.K. Amelioration of soil acidity, Olsen-P, and phosphatase activity by manure- and peat derived biochars in different acidic soils. Arab. J. Geosci. 2018, 11, 272. [CrossRef]

82. Li, J.H.; Lv, G.H.; Bai, W.B.; Liu, Q.; Zhang, Y.C.; Song, J.Q. Modification and use of biochar from wheat straw (Triticum aestivum L.) for nitrate and phosphate removal from water. Desalin. Water Treat. 2016, 57, 4681-4693.

83. Shi, R.Y.; Ni, N.; Nkoh, J.N.; Dong, Y.; Zhao, W.R.; Pan, X.Y.; Li, J.Y.; Xu, R.K.; Qian, W. Biochar retards Al toxicity to maize (Zea mays L.) during soil acidification: The effects and mechanisms. Sci. Total Environ. 2020, 719, 137448. [CrossRef] [PubMed] 